\title{
Reserva de Ley Penal y Autonomía Local
}

\author{
Casimiro López García \\ Interventor. Tesorero de Administración Local. \\ Letrado del Ayuntamiento de Torrelavega.
}

\begin{abstract}
Sumario: I. CONCEPTO CONSTITUCIONAL DE LA RESERVA DE LEY.-II. RESERVA DE LEY Y AUTONOMÍA TERRITORIAL. - III. ALCANCE DE LA RESERVA DE LEY EN MATERIA SANCIONADORA.-IV. RELACIONES DE SUJECIÓN ESPECIAL. - V. LIMITACIONES AL CARACTER INSTRUMENTAL DE LA POTESTAD SANCIONADORA DE LAS COMUNIDADES AUTÓNOMAS. 5.1 Existencia de limitaciones constitucionales específicas. - VI. PODER SANCIONADOR, RESERVA DE LEY Y CORPORACIONES LOCALES. - VII. NECESARIA NATURALEZA POLÍTICA DE LA AUTONOMÍA LOCAL. - VIII. NUEVAS PRROPUESTAS DOCTRINALES. - IX. LA STC 132, 2001, DE 8 de JUNIO. 9.1. Diferente finalidad de la reserva de ley en materia penal y fiscal. 9.2. Criterios delimitadores del poder sancionador local: la definición del interés local. 9.3. Alcance y contenido de la «interpositio legis».-X. CRÍTICA DE LA DOCTRINA CONSTITUCIONAL EN MATERIA DE COMPETENCIAS SANCIONADORAS LOCALES.
\end{abstract}

\section{CONCEPTO CONSTITUCIONAL DE LA RESERVA DE LEY}

La construcción dogmática del principio de Reserva de Ley se ha consolidado en la evolución del derecho público europeo en paralelo con el principio democrático. La Reserva de Ley envuelve una garantía esencial del funcionamiento del Estado de Derecho al personificar y plasmar mejor que ninguna otra institución la teoría de la división de poderes y los valores trascendentales de igualdad y libertad que alumbró la revolución Francesa arrumbando con el «Ancien Régimen» e inaugurando la modernidad. Los intereses, bienes y derechos más importantes para los ciudadanos - por supuesto, los impuestos y las sanciones-quedan a salvo de las normas o actuaciones del poder ejecutivo. Sólo por Ley se pueden regular y garantizar el ejercicio de los derechos y de las obligaciones fundamentales. ${ }^{1}$

La institución se moderniza por el primer constitucionalismo europeo del Estado Liberal del ochocientos, bajo el influjo de los grandes pensadores de la Ilustración, a favor y en beneficio de los ciudadanos, para asegurar que la regu-

\footnotetext{
1 La institución de la reserva de ley será una de las preocupaciones esenciales del Estado Liberal del siglo XIX, y de las sucesivas revoluciones liberal-burguesas que lo consolidaron (1830, 1848, 1868); entre otras definiciones, se suele citar la de OTTO MAYER, para quien la reserva de ley es aquel ámbito de actuación excluido de la iniciativa normativa del poder ejecutivo. Quedaban afectadas por la garantía toda normativa en materia de libertad personal, derechos de propiedad, y cargas sociales. El establecimiento de la Reserva de ley, que hoy contemplamos como una conquista general imprescindible para la efectividad de los derechos fundamentales en nuestro Estado Social y Democrático de Derecho, en aquel momento traduce el triunfo de la burguesía en el Estado Liberal del siglo XIX y sirve a los intereses de la propiedad privada y la libertad individual.
} 
lación y el establecimiento de los impuestos, de los delitos y sus penas, el derecho de propiedad y los derechos fundamentales y libertades políticas, quedan en poder de las cámaras legislativas elegidas por sufragio, primero censitario y luego universal. Para extender su ámbito y objeto al Estado Social y Democrático de Derecho de la segunda mitad del S. XX a los derechos sindicales, económicos y sociales. Su fuerza expansiva se dirige ahora a garantizar la efectividad de los derechos fundamentales de última generación; entre otros, el acceso a la cultura, a la vivienda, al medio ambiente, y a garantizar la participación en todos los ámbitos de la actividad pública. Puede afirmarse que la reserva de Ley es una garantía constitucional común en Europa occidental que cristaliza como ninguna otra los fundamentos y principios del Estado Liberal primero y del Estado Social y Democrático en la actualidad.. Constituye, en definitiva, un patrimonio jurídico común que identifica mejor que ninguna otra institución jurídica el concepto geopolítico de «occidente» y facilita el proceso de la integración europea. Alcanza así su verdadero sentido aquella institución medieval del principio de reserva de Ley, que estaba caracterizado por unas cortes estamentales - nobleza, clero y, en menor medida, la burguesía naciente - que eran convocadas por los monarcas para solicitar autorización para el establecimiento de levas y tributos, y que fueron suprimidas por el monarca absoluto del Estado Moderno ${ }^{2}$.

La Constitución Española de 1978 (CE) anuda el concepto de reserva de Ley al desarrollo de los derechos fundamentales y de las libertades públicas que sólo pueden regularse por ley que además tiene que ser orgánica ${ }^{3}$ (artículo 81 de la CE); esta protección de necesaria regulación por Ley de las Cortes Generales se completa en la CE 78 con la garantía adicional de un recurso judicial especial y sumario ad hoc, y con el establecimiento de un recurso de amparo, ante el propio Tribunal Constitucional, configurado como último remedio, en el artículo 53.2 CE, que alcanza al núcleo esencial de los derechos fundamentales reconocidos en los artículos 15 a 29 y 30, y por una interpretación extensiva e integrada de la doctrina constitucional sobre los efectos del artículo 14 (derecho a la igualdad) al artículo $31 \mathrm{CE}$, que obliga al sostenimiento común y general de los servicios públicos. Junto con este núcleo esencial del contenido de la reserva de ley constituido por los derechos y libertades personales y políticas (derecho a la vida, de reunión, de asociación, pensamiento y libre difusión de

\footnotetext{
2 El Tribunal Constitucional - entre otras muchas, Sentencias de 24 de julio de 1984, y 17 de febrero de 1987 - así lo entiende, cuando identifica reserva de ley con autoimposición: «el principio de legalidad en materia tributaria responde en esencia a la vieja idea, cuyo origen se remonta a la Edad Media, de garantizar que las prestaciones que los particulares satisfacen a los Entes públicos sean previamente consentidas por sus representantes; la reserva de ley se configura como una garantía de autoimposición de la comunidad sobre sí misma y, en última instancia, como una garantía de la libertad patrimonial y personal del ciudadano. En el Estado social y democrático de Derecho la reserva cumple sin duda otras funciones, pero la finalidad última (...) continúa siendo la de asegurar que cuando un ente público impone coactivamente una prestación patrimonial a los ciudadanos, cuente para ello con la voluntaria aceptación de sus representantes.»
}

3 El artículo 81 de la CE 78, refiere las leyes orgánicas al desarrollo de los derechos fundamentales y las libertades públicas, de la sección 1. a del Capítulo II del Titulo 1 de la CE, artículos 14 a 29 y 30. 
las ideas, participación política, educación $)^{4}$, la reserva legislativa extiende su protección al resto de los derechos reconocidos en la sección segunda del capítulo II del título I de la CE, artículos 32 a 39, que sólo podrán desarrollarse por Ley, que además deberá respetar su contenido esencial, quedando bajo la salvaguardia del propio TC a través del recurso de inconstitucionalidad ex artículo 161.1 a) CE. Los derechos incluidos en el Capítulo III «De los Principios Rectores de la Política Social y Económica» gozan de una mayor libertad de configuración, al quedar condicionados a lo que dispongan las leyes que los desarro$l_{l e n}^{5}$, sin que exista un contenido esencial a priori.

\section{RESERVA DE LEY Y AUTONOMÍA TERRITORIAL}

En un estado compuesto y políticamente descentralizado como el Estado de las Autonomías de la CE 78, las relaciones entre el Estado central y los «Estados federados», a la hora de establecer tributos o determinar los distintos ámbitos de colaboración normativa, no serán fáciles ${ }^{6}$. En materia financiara, exigen la previa intervención del Estado para establecer y autorizar tributos, sin que tales regulaciones puedan agotar la materia, que deberá desarrollarse por las Comunidades Autónomas (CCAA) y por las Entidades Locales (EELL) de acuerdo con el derecho a la autonomía de las regiones, nacionalidades y entes locales que predican los artículos 2, 137 y 140 de la CE. La «interpositio legis» juega aquí, a la hora de definir y relacionar la Autonomía Tributaria de las EELL, e incluso de las CCAA como una auténtica reserva de competencia del Estado al margen de los títulos constitucionales de atribución de competencial ${ }^{7}$.

\footnotetext{
4 Artículos 15 a 29 y 30 de la CE de 1978, que se integran en la sección primera del capítulo II del Título Primero «de los derechos fundamentales y de las libertades públicas», superprotegidos por el principio de reserva de ley que además tiene que ser orgánica (art. $81 \mathrm{CE}$ ) y por sendos recursos judiciales especiales ante la JCA y de «amparo» como última solución ante el propio TC, según dispone el artículo $53 \mathrm{CE}$.

5 Pérez LuÑo A. E., Derechos Humanos, Estado de Derecho y Constitución. Ed. Tecnos, Madrid, 1999. A pesar de las opiniones doctrinales es contra, el paso del tiempo nos ha demostrado que no tienen una protección jurídica tan débil. Su fuerza reside en la propia naturaleza normativa de la propia Constitución en cuanto tiene de mandato directo a los distintos Poderes del Estado. El artículo 9. 1 CE establece la primacía y obligatoriedad directa de la Constitución: Los ciudadanos y a los poderes públicos están sujetos a la misma. Sus pronunciamientos y mandatos no son meros deseos o declaraciones de intenciones; por el contrario, son órdenes que obligan a regular y desarrollar por Ley la práctica totalidad de los denominados derechos fundamentales de tercera generación: sociales, culturales y medioambientales. Los llamados «derechos culturales», conforman, entre otros, los denominados derechos fundamentales de «tercera generación», pues en su proceso de positivización en los textos constitucionales, hacen acto de presencia después de los derechos civiles y de los derechos políticos y económico-sociales.

6 E. GarCía de ENTERRía (1990) Curso de Derecho Administrativo, (1990) 5. ${ }^{a}$ páginas 302. Editorial Cívitas, Madrid. El núcleo de esta «concurrencia» legislativa está constituido por aquellas materias en las que, de modo expreso, el Estado se reserva la legislación básica, correspondiendo a las Comunidades Autónomas el desarrollo normativo de dicha legislación básica, bases o normas básicas o condiciones básicas.

7 De ahí que la STC 14/1986 afirmase que la Hacienda regional no es «tanto una competencia que se reconoce a las Comunidades Autónomas cuanto una exigencia previa o paralela a la propia organización autónoma» (fundamento jurídico $2 .^{\circ}$ ).
} 
La CE reconoce a las Corporaciones locales el poder de «establecer y exigir tributos, de acuerdo con la Constitución y las leyes» (art. 133.2), confiriendo así a dicho poder un rango constitucional que impide su desconocimiento por el Estado o por las Autonomías, y es la efectiva garantía de su existencia, aunque se trate de un poder derivado, al identificarse el poder originario para establecer tributos con la soberanía del Estado, que reside en el pueblo Español del que emanan todos los poderes del Estado. ${ }^{8}$

El ámbito de la reserva de Ley no puede utilizarse para desapoderar a los municipios de cualquier intervención en la ordenación del tributo o en su exigencia, tampoco podrá el legislador abdicar de toda regulación directa en el ámbito parcial que así le reserva la Constitución (art. 133,1 y 2), le corresponde a la Ley del Estado la creación ex novo de cada figura tributaria y la determinación de su contenido esencial. Las Corporaciones locales podrán exigir tributos de acuerdo con la Constitución y de conformidad con lo dispuesto en las leyes. El legislador no puede desconocer al regular el sistema tributario local las exigencias de la reserva de Ley, y no puede limitarse a una mera mediación formal, en cuya virtud se apodere a las Corporaciones locales para conformar, sin predeterminación alguna, el tributo de que se trate ${ }^{9}$; no son de recibo las cláusulas meramente habilitantes que den cobertura a una regulación por completo autónoma de los Ayuntamientos en materia fiscal ${ }^{10}$.

El principio democrático que rige en la CE para la constitución de los Ayuntamientos (art. 140 de la Constitución) es el que real y definitivamente fundamenta el poder de autodisposición en el establecimiento de los deberes tributarios. Este poder representativo configura la naturaleza esencialmente política de la autonomía municipal y no sólo administrativa - si sólo tuviera este carácter y naturaleza no podría cumplir con las exigencias democráticas del principio de reserva de Ley en materia tributaria y no tendría posibilidad de intervenir en la regulación de sus tributos - pero nunca podrá colmar todos los requisitos y las exigencias de la reserva de Ley que, en materia fiscal, está también al servicio de otros principios y finalidades constitucionales ${ }^{11}$. $\mathrm{Y}$ así está implícitamen-

\footnotetext{
8 Artículos 1.2 y $2 \mathrm{CE}$

9 STC 19/87 Fto. Jco. 4 ॰ $^{4}$ «in fine»: «... Las Leyes reclamadas por la Constitución en este último precepto no son, por lo que a las Corporaciones Locales se refiere, meramente habilitadoras para el ejercicio de una potestad tributaria que originariamente sólo corresponde al Estado. Son también Leyes ordenadoras — siquiera de modo parcial, en mérito de la autonomía de los municipios - de los tributos así calificados de «locales», porque la Constitución encomienda aquí al legislador no sólo el reconocer un ámbito de autonomía al ente territorial, sino también garantizar la reserva legal que ella misma establece (art. 31.3), y cuyo sentido hemos recordado con anterioridad.»

10 conclusión que, en estos términos absolutos, sería incluso inexacta respecto de entes dotados de potestad legislativa, como son las Comunidades Autónomas (arts. 149.1, 1..ํ, 156.1 y 157.3 de la Constitución).

11 GARCía AÑoveros y José Manuel TEJERIZO LóPEZ: «Las relaciones entre los diferentes niveles del sistema tributario español a la luz de la reforma de las Haciendas Locales» Tributos Locales, número 23, mayo de 2.003, MADRID, entienden que la ausencia de autonomía financiera es un síntoma claro de ausencia de autonomía política, tal como advirtiera Rafael CALVO ORTEGA.
} 
te reconocido en la propia CE al autorizar a las Entidades Locales a establecer tributos, lo que necesariamente implica un mínimo poder de decisión en cuanto al establecimiento de figuras tributarias, previamente definidas en sus contornos básicos y elementales por la Ley del Estado y a la determinación de la presión fiscal. En otro caso, carece de sentido la configuración constitucional de los Ayuntamientos bajo el principio democrático ${ }^{12}$, y ordenar su gobierno y administración al Alcalde y a los Concejales.

En materia tributaria, el concepto constitucional de la reserva de Ley exige la previa determinación por una ley del Estado de los elementos esenciales del tributo local: la determinación de los elementos esenciales del tributo corresponde necesariamente a la Ley del Estado, sin perjuicio de que la propia naturaleza del Estado Español de $1978^{13}$ y del principio de Autonomía Territorial que le informa, obliga al legislador, en materia de tributos locales, a reconocer a las Corporaciones Locales una intervención en el establecimiento o en la exigencia de aquéllos. El detalle de la ley del Estado será máximo a la hora de definir el hecho imponible - verdadero núcleo duro de la reserva de ley en materia tributaria, que permanecerá indisponible al Poder Local de ordenanza fiscal-.${ }^{14}$ El legislador estatal está obligado a una regulación parcial de los tipos del impuesto, predisponiendo criterios o límites para su ulterior definición por cada Corporación Local, a la que corresponderá ya, en el ejercicio de su autonomía y en atención a las peculiaridades de su hacienda propia, la precisión de cuál sea el tipo que, de acuerdo con el marco legal, haya de ser aplicado en su respectivo ámbito territorial ${ }^{15}$. La Autodisposición o aprobación/autorización de los ciudadanos sobre los propios impuestos y sobre el resto de los gastos del Estado está en el origen de la democracia representativa moderna. Así aparece en la propia doctrina de la STC 233/99, para justificar el cumplimiento de las exigencias del principio de Reserva de Ley por el Pleno del Ayuntamiento.

12 Ramón Martín Mateo y F. Sosa WAGNER «50 Años en la Administración Local» RAP, N. ${ }^{\circ}$ 150, septiembre-diciembre de 1999, CEAC, MADRID.

13 STC 32/81. Concepto de Autonomía Territorial.

14 STC núm. 221/1992 (Pleno), de 11 diciembre Alcance de la reserva de Ley según lo distintos elementos del tributo En el resto de los elementos esenciales del Tributo, como la definición de la base imponible y del tipo, en cuanto elementos necesarios para la determinación del importe de la cuota tributaria -también la base imponible es un elemento esencial del tributo-, el grado de determinación de la Ley del Estado será mayor o menor según se trate de impuestos o de otras prestaciones de naturaleza pública - tasas, contribuciones especiales - , que tienen mayor presencia de la voluntad particular y pueden permitirse una regulación local más completa y compleja a la hora de definir bases y tipos dentro de los criterios generales establecidos por la ley del Estado.

15 STC 19/87, Fto. Jco. 4. ${ }^{\circ}$ último párrafo: «...Siempre será posible una intervención municipal, que habrá de ser encauzada por la previa regulación del Estado. El legislador no puede renunciar al establecimiento de limitaciones en el ejercicio de la potestad tributaria de las Corporaciones Locales. La renuncia plena por la Ley a todo encuadramiento normativo de la potestad tributaria local no se acomoda, en definitiva, con lo dispuesto en el art. 133.2 de la Constitución ni con la general reserva de Ley establecida en este ámbito por el artículo. 31.3 de la Norma fundamental, pues esta reserva - como hemos indicado - está también al servicio de la procuración del «sistema» tributario al que se refiere el apartado primero del precepto constitucional citado y de la igualdad de los ciudadanos dentro de él y no se compadece, por ello, con habilitaciones indeterminadas para la configuración de los elementos esenciales de los tributos.» 
Si el principio democrático que rige la constitución y la toda la vida municipal, junto con la previsión constitucional de una participación de los entes locales en el establecimiento de sus tributos propios, ha facilitado una formulación flexible del principio de reserva de Ley en relación con la autonomía local en la doctrina constitucional, que desde la STC 1987 autoriza una presencia no meramente testimonial del poder local, la ausencia de toda referencia o listado de competencias locales en la CE 78, y un concepto estricto de la doctrina constitucional en materia de reserva de Ley penal, que identifica la materia penal con la sancionadora y reduce a su mínima expresión el poder reglamentario, tendrá efectos devastadores sobre el poder normativo local. La identificación de la ordenanza local con el reglamento estatal está en el origen de esta doctrina constitucional y de la práctica totalidad de la jurisprudencia del TS que requiere la previa definición de los tipos y de las sanciones locales por las leyes del Estado o de la Comunidad Autónoma que, de acuerdo con el sistema legal de asignación y atribución de poderes a los EELL en los distintos sectores materiales de la actividad administrativa, reserven o atribuyen competencias. Para esta jurisprudencia, no existe un poder autónomo local para regular y definir ilícitos e imponer las pertinentes sanciones. La vinculación negativa de las ordenanzas locales que figura en el artículo 55 del Decreto Legislativo 781/86, de 18 de abril, por el que se aprueban las disposiciones legales vigentes en Régimen Local, en el sentido de poder aprobar ordenanzas en lo que no se opongan a las leyes, no cumple las exigencias del principio de reserva legislativa, tampoco el cuadro de sanciones del artículo 59 al carecer de gradación en función de la gravedad del ilícito, de la culpabilidad del infractor y de la propia y necesaria definición del tipo de comportamiento ilícito al que se anuda la sanción.

\section{ALCANCE DE LA RESERVA DE LEY EN MATERIA SANCIONADORA}

Si el TC formula un concepto de reserva de Ley gradual y flexible en materia tributaria, que tiene que cohonestarse con las autonomías territoriales y dejar un espacio normativo suficiente a favor de los entes autonómicos y locales que tienen reconocido directamente por la CE poder para exigir tributos, SSTC $179 / 85,19 / 87$ y 233/99, que terminan por reconocer una competencia normativa plenamente política del Pleno para regular sus propios tributos dentro del marco de la Ley, no ocurrirá lo mismo en materia de derecho penal y del derecho administrativo sancionador, que desde las primeras sentencias ${ }^{16}$ se configu-

16 STC 18/81 F 2: Para llevar a cabo dicha interpretación, ha de recordarse que los principios inspiradores del orden penal son de aplicación, con ciertos matices, al derecho administrativo sancionador, dado que ambos son manifestaciones del ordenamiento punitivo del Estado, tal y como refleja la propia Constitución (artículo 25, principio de legalidad), y una muy reiterada jurisprudencia de nuestro Tribunal Supremo (Sentencias de la Sala Cuarta de 29 de septiembre, 4 y 10 de noviembre de 1980, entre las más recientes), hasta el punto de que un mismo bien jurídico puede ser protegido por técnicas administrativas o penales, si bien en el 
ra como una manifestación única del ordenamiento punitivo del Estado, tal y como refleja la propia Constitución en el artículo 25. Sin que exista diferencia sustancial entre el ordenamiento penal propiamente dicho y el Derecho administrativo sancionador y que los principios inspiradores del orden penal son de aplicación, con ciertos matices, al derecho administrativo sancionador, al igual que los principios esenciales reflejados en el artículo 24 de la Constitución en materia de procedimiento han de ser aplicables a la actividad sancionadora de la Administración, para preservar los valores esenciales del Estado de Derecho que se encuentran reconocidos expresamente en el artículo 9 CE. ${ }^{17}$

Para esta primera doctrina constitucional, en la regulación de infracciones y sanciones administrativas, el alcance de la colaboración reglamentaria será mínimo. La STC 83/94, de 24 de julio, F 4: «Este principio de reserva de ley entraña, en efecto, una garantía esencial de nuestro Estado de Derecho, y como tal ha de ser preservado. Su significado último es el de asegurar que la regulación de los ámbitos de libertad que corresponden a los ciudadanos dependa exclusivamente de la voluntad de sus representantes, por lo que tales ámbitos han de quedar exentos de la acción del ejecutivo y, en consecuencia, de sus productos normativos propios, que son los reglamentos. El principio no excluye, ciertamente, la posibilidad de que las leyes contengan remisiones a normas reglamentarias, pero sí que tales remisiones hagan posible una regulación independiente y no claramente subordinada a la Ley, lo que supondría una degradación de la reserva formulada por la Constitución en favor del legisla$d o r »$. Se limita el alcance de las remisiones o habilitaciones legales a la potestad reglamentaria al mínimo posible, no sólo se requiere una previa habilitación o regulación mínima o de principios con rango de ley; la definición de las infracciones, la graduación de las sanciones y el procedimiento sancionador en todos sus aspectos básicos quedan reservadas por entero a la Ley. El ejercicio de la potestad reglamentaria en materia sancionadora complementa la regulación legal cuando resulte indispensable por motivos técnicos o para optimizar el cumplimiento de las finalidades propuestas por la Constitución o por la propia Ley ${ }^{18}$. Quedan proscritas las cláusulas de deslegalización de la materia san-

\footnotetext{
primer caso con el límite que establece el propio artículo 25 , en su número $3 . .^{\circ}$, al señalar que la Administración Civil no podrá imponer penas que directa o subsidiariamente impliquen privación de libertad. Debe añadirse que junto a las diferencias apuntadas en la aplicación de los principios inspiradores existen otras de carácter formal en orden a la calificación (delito o falta, o infracción administrativa), la competencia, y el procedimiento (penal o administrativo con posterior recurso ante la jurisdicción contencioso-administrativa); ello, además del límite ya señalado respecto al contenido de las sanciones administrativas.
}

17 J. TORNOS MAS: «Relación entre la Ley y el Reglamento. Reserva legal y Revisión Normativa. Algunos aspectos conflictivos a la luz de la jurisprudencia del TC» RAP, NUM 100, PAG 471 y ss. (CEPC) 1983. MADRID.

18 Es doctrina reiterada de este Tribunal (SSTC 42/1987, de 7 de abril, F. 2, y 133/1999, de 15 de julio, F. 2, entre otras) que el art. 25.1 CE reserva a la Ley la tipificación de los elementos esenciales de las infracciones administrativas, y que al Reglamento puede corresponder, en su caso, el desarrollo y precisión de los tipos de infracciones previamente establecidos por la Ley. Este canon de constitucionalidad ha sido precisado por este Tribunal en numerosas Sentencias. En lo que ahora importa, hemos dicho reiteradamente que, en materia 
cionadora, cuando impliquen una total abdicación por parte del legislador de su facultad para establecer reglas limitativas, transfiriendo esta facultad al titular de la potestad reglamentaria, sin fijar ni siquiera cuáles son los fines u objetivos que la reglamentación ha de perseguir. Las habilitaciones genéricas a favor de la potestad reglamentaria sancionadora son inconstitucionales por equivaler a una deslegalización que viola directamente la reserva de Ley impuesta por el artículo 25 de la CE: «nadie puede ser condenado o sancionado por acciones $y$ omisiones que en el momento de producirse no constituyan delito, falta o infracción administrativa, según la legislación vigente en aquel momento» ${ }^{19}$.

Aunque el propio TC pretenda que la reserva de la Ley contenida en el art. 25.1 de la Constitución despliegue una eficacia semejante a las que establecen otras normas constitucionales, y no excluye «la posibilidad de que las Leyes contengan remisiones a normas reglamentarias, pero sí que tales remisiones a normas reglamentarias hagan posible una regulación independiente y no claramente subordinada a la Ley» - STC 83/1984, de 24 de julio - ${ }^{20}$. Tal semejanza no existe, al incorporar el artículo $25.1 \mathrm{CE}$ la regla «nullum crimen nulla poena sine lege», que cubre todo el ámbito del derecho sancionador, identificando un poder sancionador estatal único que incluye al ordenamiento sancionador administrativo. Al amparo de esta regla, el TC formulará desde sus primeras sentencias la teoría de la doble garantía del artículo $25 \mathrm{CE}$. La primera, de orden material y alcance absoluto, tanto por lo que se refiere al ámbito estrictamente penal como al de las sanciones administrativas, refleja la especial trascendencia del principio de legalidad en dichos ámbitos limitativos de la libertad individual, y se traduce en la imperiosa exigencia de predeterminación normativa de

de tipificación de infracciones, el art. 25.1 CE prohibe la remisión de la Ley al Reglamento sin una previa determinación de los elementos esenciales de la conducta antijurídica en la propia Ley; entre otras, SSTC 42/1987, F. 2; 305/1993, de 25 de octubre, F. 3; 341/1993, de 18 de noviembre F. 10 b; y 116/1999, de 17 de junio F. 16.

19 En cuanto al alcance de los Decretos Leyes, el mandato del art. 86.1 CE de no poder afectar a los derechos, deberes y libertades de los ciudadanos regulados en el título I C. E. Ha señalado así que no cabe una interpretación de esa restricción que suponga el vaciamiento de la figura del Decreto-Ley, y su inutilidad absoluta, lo que resultaría del otorgamiento al verbo «afectar» de un contenido literal amplísimo (STC 111/1983, de 2 de diciembre, fundamento jurídico $8 .^{\circ}$ ), y ha indicado igualmente que, en consecuencia, la prohibición a que nos referimos ha de entenderse como impeditiva, no de cualquier incidencia en los derechos recogidos en el título I, sino de una regulación por Decreto-Ley del régimen general de los derechos, deberes y libertades contenidos en ese título, así como de que «por Decreto-Ley se vaya en contra del contenido o elementos esenciales de alguno de tales derechos», habida cuenta de la configuración constitucional del derecho de que se trate, e incluso de su posición en las diversas secciones en el texto constitucional, STC 111/1983, F 8 .

20 Este principio de reserva de ley entraña, en efecto, una garantía esencial de nuestro Estado de Derecho, y como tal ha de ser preservado. Su significado último es el de asegurar que la regulación de los ámbitos de libertad que corresponden a los ciudadanos dependa exclusivamente de la voluntad de sus representantes, por lo que tales ámbitos han de quedar exentos de la acción del ejecutivo y, en consecuencia, de sus productos normativos propios, que son los reglamentos. El principio no excluye, ciertamente, la posibilidad de que las leyes contengan remisiones a normas reglamentarias, pero sí que tales remisiones hagan posible una regulación independiente y no claramente subordinada a la Ley, lo que supondría una degradación de la reserva formulada por la Constitución en favor del legislador 


\section{RESERVA DE LEY PENAL Y AUTONOMÍA LOCAL}

las conductas ilícitas y de las sanciones correspondientes. La segunda, de carácter formal, es la que traduce el principio de reserva de ley, al referirse al rango necesario de las normas tipificadoras de aquellas conductas y reguladoras de estas sanciones. En este sentido, el término «legislación vigente» contenido en dicho art. 25.1 CE constitucionaliza el principio de legalidad penal de manera tal que prohibe que la punibilidad de una acción u omisión esté basada en norma distinta o de rango inferior a la legislativa (STC 8/1981, de 30 de marzo, fundamento jurídico 3), para añadir que los principios inspiradores del orden penal son de aplicación, con ciertos matices, al derecho administrativo sancionador, dado que ambos son manifestaciones del ordenamiento punitivo del Estado, tal y como refleja la propia Constitución (STC 18/1981, de 8 de junio, fundamento jurídico 2), y que, en consecuencia, la potestad sancionadora de la Administración encuentra en el art. 25.1 CE la limitación del principio de legalidad, que exige una cobertura con rango de ley formal de la potestad sancionadora. Los poderes sancionatorios en manos de la administración tienen carácter excepcional y no son concebibles sin previa habilitación legal expresa con determinación completa de las infracciones, sus penas y con establecimiento de los criterios para su aplicación ${ }^{21}$.

Junto a esta doble garantía, que trae consigo la necesidad de contar siempre con una norma con rango de ley en la determinación de las infracciones y sus correspondientes sanciones, resultan de aplicación al derecho sancionador los principios inspiradores del derecho penal. Lo que concede un plus de protección en materia de garantías procedimentales que incluye el derecho a la presunción de inocencia y a la defensa letrada, con el característico efecto suspensivo de la sanción hasta que alcance firmeza en vía administrativa, y con sus consecuencias sobre los efectos de la tutela judicial efectiva en materia de justicia cautelar en recursos contra la imposición de sanciones. El F 4 de la STC 56/98, 26 de marzo, ratifica y completa una doctrina constitucional plenamente consolidada: «Los principios esenciales reflejados en el art. 24 de la Constitución en materia de procedimiento han de ser aplicables a la actividad sancionadora de la Administración» (STC 18/1981, fundamento jurídico 2), a que entre dichos principios se encuentra el que inspira el contenido del derecho a la presunción de inocencia (STC 76/1990, fundamento jurídico 8. ${ }^{\circ}$ : «no puede suscitar ninguna duda que la presunción de inocencia rige sin excepciones en el ordenamiento sancionador y ha de ser respetada en la imposición de cualesquiera sanciones, sean penales, sean administrativas»), y a que aquella aplicación no tiene un alcance «literal», sino el que requiere la preservación de los valores esenciales que se encuentran en la base del precepto, y la seguridad jurídica que garantiza el art. 9 de la Constitución». Doctrina que incluye la traslación a los procedimientos administrativos sancionadores de las garantías constitucionales consagradas en el art. 24 , condicionada a que se trate de garan-

21 José SuAY RinCón (1983): «El Derecho Administrativo Sancionador: Perspectivas de Reforma» RAP, num 109, pags 185 y ss (CEPC) 1986 MADRID. 
tías que resulten compatibles con su naturaleza ${ }^{22}$; aunque no exista un derecho absoluto a la defensa letrada, ${ }^{23}$ resultan de aplicación al procedimiento administrativo sancionador el derecho a ser informado de la acusación - con la ineludible consecuencia de la inalterabilidad esencial de los hechos imputados; el derecho a la presunción de inocencia, que implica que la carga de la prueba de los hechos constitutivos de la infracción recaiga sobre la Administración, con la prohibición de la utilización de pruebas obtenidas con vulneración de derechos fundamentales; el derecho a no declarar contra sí mismo; y, en fin, el derecho a utilizar los medios de prueba adecuados para la defensa, del que se deriva que la denegación inmotivada de medios de prueba puede vulnerar el art. 24.2 CE si resulta decisiva en términos de defensa, según una continuada doctrina constitucional, entre otras, S 44/83, de 24 de mayo, F 3; 7/98, de 13 de enero, F 5 y 54/2003, de 24 de marzo, F3. En definitiva, el principio «pro accione»-el derecho a obtener una tutela judicial efectiva- es más fuerte en materia sancionadora que cuando estén en juego otros derechos fundamentales, al adquirir aquí verdadero sentido el derecho a la libertad y a la seguridad, junto con el derecho a la igualdad y con la prohibición de toda discriminación, verdadera raíz de todos los derechos fundamentales y libertades públicas que reconoce y protege nuestra Constitución, amén de los principios jurídicos básicos de un Estado de Derecho, que garantiza el artículo 9.3 CE, entre otros, la seguridad jurídica, la irretroactividad de las normas sancionadoras y la interdicción de la arbitrariedad ${ }^{24}$.

No obstante, La evolución inmediata de la doctrina constitucional, entre otras la S 42/87, establece un alcance de la reserva de Ley menos estricto en relación con la regulación de las infracciones y sanciones administrativas como por referencia a los tipos y sanciones penales. Esta mayor flexibilidad, se fundamenta en razones que atañen al modelo constitucional de distribución de las potestades públicas, y por el carácter en cierto modo insuprimible de la potestad reglamentaria en ciertas materias. Se reconoce una potestad reglamentaria sancionadora subordinada a la existencia de previa definición por Ley formal de los distintos tipos de ilícitos y su calificación en relación con la gravedad de la infracción administrativas, que concede una cierta libertad a la Administración para establecer un desarrollo reglamentario de los princi-

22 STC 14/1999, de 22 de febrero, F. 3) también con otras palabras en múltiples resoluciones, postulando una aplicación de las garantías procesales al procedimiento administrativo sancionador «en línea de principio» (STC 66/1984 [], fundamento jurídico 1.. ), cautelosa (SSTC 246/1991, 197/1995 y respetuosa con la naturaleza de este procedimiento (SSTC 22/1990, 246/1991), y rechazando que dicha aplicación pueda realizarse de modo mimético, inmediato (STC 181/1990 (STC 197/1995).

$23 \mathrm{~S} 74 / 85$, de 18 de junio, requiere sólo «en forma y grado estimables como proporcionados a la falta, ala sanción y al procedimiento», pues tal derecho, como resulta del art. 6.3 de la Convención Europea de Derechos Humanos sólo existe claramente en los procesos judiciales, y además no en todos los casos, sino cuando los intereses de la justicia lo requieran.

24 Manuel REBOLLO PUIG «Juridicidad, legalidad, y reserva de ley como límites a la potestad reglamentaria del Gobierno» RAP, num 125 mayo-agosto de 1991, pags. 7-173, (CEPC) MADRID. 
pios y tipos generales establecidos a por ley formal. Sin abandonar la teoría de la doble garantía de la reserva de ley y su proyección al Derecho administrativo, se admite por necesidad un ámbito natural de colaboración y desarrollo a la potestad reglamentaria más allá de la ineludible necesidad técnica: el reglamento sancionador tiene así un campo propio de colaboración necesaria con la ${ }^{25}$ ley, tanto para el desarrollo de las leyes generales de procedimiento y régimen jurídico de las administraciones como en el desarrollo y complemento de los regímenes sancionadores de las distintas leyes de la actividad administrativa ${ }^{26}$.

\section{RELACIONES DE SUJECION ESPECIAL}

Junto a las sanciones de protección general, se han distinguido en nuestra doctrina (Enterría) las denominadas sanciones de autoprotección administrativa o sanciones disciplinarias, que coinciden con el denominado régimen de sujeción especial definido por la doctrina alemana. La relación especial tiene su fundamento en la previa existencia de una situación o relación jurídica especial del ciudadano con la administración, que habilita a ésta para exigir unas determinadas prestaciones o comportamientos con fundamento en existir una relación de servicio (funcionarios); en la autotutela de las profesiones liberales (colegios profesionales); en la definición del régimen de sanciones de los servicios públicos y, por supuesto, de los internos en establecimientos penitenciarios, que cumplen penas de privación de libertad. Se trata de una figura de contornos imprecisos que sirve para justificar la necesidad de un poder reglamentario cuasi independiente y no por completo subordinado a la ley en estos ámbitos. Los peligros de esta pretendida deslegalización en materia sancionadora, al amparo de una teoría que carece de perfiles claros que, por la vía de la inclusión del usuario de servicios públicos, tiene un evidente aspecto extensivo a toda la materia de servicio público ${ }^{27}$, se han valorado perfectamente por la doctrina del TC para establecer un concepto restrictivo del alcance de las relaciones de «es-

\footnotetext{
25 La tipicidad se presenta, por ello, como descripción estereotipada de las acciones o de las omisiones incriminadas, con indicación de las simétricas penas o sanciones: (SSTC 2/1981, 37/1982, 62/1982, 182/1990, 102/1994 y 120/1994, que, a su vez, veda la aplicación analógica de las normas penales y su interpretación extensiva (STC 111/1993). A esas exigencias del principio de legalidad en este ámbito, se añade también la de que «las reglas de imputación» vengan predeterminadas en Norma con rango de Ley, como corrobora la STS de 27 de marzo de 1995.

26 Gonzalo QUiNTERo OLIVARES «La Autotutela, los Límites al Poder Sancionador de la Administración Pública y los Principios Inspiradores del Derecho Penal» RAP num 126, septiembre-diciembre 1991, pags. 253 y ss CEPC MADRID.

27 Lo que supondría volver a la situación anterior a la Revolución Francesa, al quedar en manos del poder ejecutivo verdaderos poderes normativos independientes en materia punitiva, con evidente quebranto del propio principio de separación de poderes y de la reserva de ley que incorpora la Constitución de 1978, que si bien no establece un sistema de separación absoluta de poderes, propia de los sistemas anglosajones en los que sólo el Juez puede imponer sanciones, y reconoce expresamente un poder sancionador en manos de la administración. Tal reconocimiento es de acuerdo con la Ley, artículos 24 y 25 CE.
} 
pecial sujeción», «de poder especial», o simplemente «especiales». Sólo será posible reconocer estas situaciones y relaciones jurídico-administrativas donde la propia Constitución o las leyes imponen límites en el disfrute de los derechos constitucionales.

Para el TC, lo importante ahora es afirmar que la categoría «relación especial de sujeción» no es una norma constitucional, sino la descripción de ciertas situaciones y relaciones administrativas donde la Constitución, o la ley de acuerdo con la Constitución, han modulado los derechos constitucionales de los ciudadanos. Sólo en el supuesto de interno en establecimiento penitenciario se autoriza una regulación en cierto sentido autónoma en el F2 de la STC 2/1987, de 21 de enero: Sin entrar aquí en el tema más general del alcance de la reserva de Ley en las sanciones administrativas, debe tenerse en cuenta que la referencia a la legislación vigente en el art. 25.1 de la Constitución, tiene un alcance diferente, al menos, en lo que se refiere a la tipificación del ilícito, cuando se trata de la determinación de contravenciones «faltas», en el seno de una relación de sujeción especial, como es la de los internos en establecimientos penitenciarios. En estos casos la reserva de Ley cumple principalmente una función de garantizar la seguridad jurídica, de modo que los internos puedan disponer de informaciones suficientes sobre las normas jurídicas aplicables en un determinado caso, y la norma debe formularse con la suficiente precisión para que el interno pueda prever razonablemente las consecuencias que puedan derivar de una determinada conducta. El interno se integra en una institución preexistente y que proyecta su «autoridad» sobre quienes, al margen de su condición común de ciudadanos, adquieren el status específico de individuos sujetos a un poder público que no es el que, con carácter general, existe sobre el común de los ciudadanos. En virtud de esa sujeción especial, y en virtud de la efectividad que entraña ese sometimiento singular al poder público, el ius puniendi no es el genérico del Estado, y en tal medida la propia reserva de Ley pierde parte de su fundamentación material, dado el carácter en cierto modo insuprimible de la potestad reglamentaria, expresiva de la capacidad propia de autoordenación correspondiente, para determinar en concreto las previsiones legislativas abstractas sobre las conductas identificables como antijurídicas en el seno de la institución. Desde luego una sanción carente de toda base normativa legal devendría, incluso en estas relaciones, no sólo conculcadora del principio objetivo de legalidad, sino lesiva del derecho fundamental considerado, pero esa base normativa legal también existiría cuando la Ley, en este caso la Ley General Penitenciaria, arts. 42 y siguientes, se remita, en la especificación y gradación de las infracciones, al Reglamento. «La «interpostio legis» es aquí meramente habilitadora de una regulación administrativa, al existir una verdadera relación especial de sujeción que arrumba con el principio de reserva de ley formal, pero que mantiene el resto de las garantías materiales del principio de legalidad (lex previa y cer$t a$ ), siempre que tales regulaciones y las propias sanciones que se impongan cuenten con la garantía de la tutela judicial efectiva, que es a la postre la ver- 
dadera garantía personal fuera de cualquier consideración en la CE, al posibilitar siempre, incluso en este caso, el sometimiento tanto de la medida individual como del propio reglamento al control y decisión del juez independiente y predeterminado por la Ley. La tutela judicial efectiva es la última ratio del estado de derecho.

La doctrina constitucional española evolucionará hacia posiciones restrictivas en materia de relaciones de sujeción especial como puede apreciarse en la STC 61/90, sobre autorización o licencia de armas; el TC reafirma aquí con rotundidad la prioridad absoluta del artículo $25 \mathrm{CE}$ - de tal forma que sólo sean infracciones las acciones y omisiones subsumibles en la norma con rango de ley -, y niega la pretensión gubernativa de calificar como sujeción especial la relación generada por la solicitud y obtención de una licencia de armas o de un permiso de caza; en el mismo sentido, excluye del concepto sujeción especial toda la materia autorizatoria, se trate de solicitudes de licencia para conducir vehículos o de obtención de permisos de transporte, de licencias para el ejercicio de la actividad publicitaria o de actividades industriales, de los contratistas de obras de las Administraciones Públicas, o de los concesionarios y gestores de los servicios públicos. En todo estos casos será necesaria la previa existencia de una Ley; ninguna de las actuaciones de comprobación, licencia o autorización, incluidos los gestores de los servicios públicos, constituyen relaciones de sujeción especial que puedan justificar la exclusión del principio de legalidad penal o la posibilidad de una remisión normativa a una reglamento más o menos independiente. Sólo cuando se trata de colegios profesionales, puede observarse una flexibilización del principio de reserva de ley, que aparece consolidada en la STC 188/2005, por entender que la sanción impuesta por el colegio profesional no infringe el principio «non bis in idem», por tratarse evidentemente de una relación de sujeción especial, que se ordena y ejerce al margen y con independencia de la administración y, fundamentalmente, por encontrar su justificación en un interés jurídicamente protegido distinto del interés general protegido por el Código Penal. Este poder disciplinario autónomo propio e independiente, en manos de los Colegios Profesionales, se reconoce quizá por contar con un refrendo constitucional expreso en el artículo 36, y porque no desapodera ni menoscaba el previo poder sancionador penal del Estado, a cuyos hechos probados en Sentencia deberá atenerse, pero que no infringe el principio «non bis in idem.» 28

28 STC 234/1991, de 10 de diciembre, F. 2. En base a tal doctrina, este Tribunal ha considerado, por ejemplo, en el que no se producía una vulneración del principio non bis in idem en un supuesto en el que un Abogado había sido sancionado penal y disciplinariamente, porque el «genérico ius puniendi del Estado ha sido ejercido sobre el hoy demandante de amparo exclusivamente por los órganos jurisdiccionales penales», y la sanción disciplinaria impuesta al mismo sujeto por los mismos hechos por el correspondiente Colegio de Abogados, en virtud de una Ley que ha delegado a estas corporaciones el ejercicio de la potestad disciplinaria en materias profesionales, tenía «un fundamento diverso del de las penas impuestas por aquellos órganos jurisdiccionales, fundamento el de aquélla que se encuentra en la función de vigilar el ejercicio de la abogacía y velar por que dicha actividad profesional se adecue a los intereses de los ciudadanos». 


\section{LIMITACIONES AL CARÁCTER INSTRUMENTAL DE LA POTESTAD SANCIONADORA DE LAS COMUNIDADES AUTÓNOMAS}

En relación con la potestad sancionadora de las Administraciones públicas, la doctrina del TC pronto establecerá su carácter instrumental en relación con el ejercicio de competencias materiales. ${ }^{29}$ La naturaleza esencialmente política de la autonomía de las Comunidades Autónomas implica que cuentan con poder sancionador en todas las materias que tengan atribuida competencia en sus respectivos Estatutos de Autonomía. La titularidad estatal o comunitaria de competencia sustantiva sectorial presume la atribución de competencia para dictar normas administrativas sancionadoras en la materia. Las normas y disposiciones que se dicten en el ejercicio de tal competencia sancionadora instrumental deberán acomodarse necesariamente a las garantías constitucionales dispuestas en este ámbito del derecho administrativo sancionador (art. 25.1 CE), y deberán cumplir con las exigencias de la doble garantía, sin que exista posibilidad alguna para el reglamento independiente en materia sancionadora ${ }^{30}$. No es necesario ni constituye requisito constitucional la previa existencia de un reconocimiento legal o estatutario de competencias específicas para que las CCAA tengan potestad sancionadora que, para esta doctrina, tienen un carácter instrumental y complementario de la competencia material o sustancial de la que resulta inseparable.

\subsection{Existencia de limitaciones constitucionales específicas}

La configuración de la potestad sancionadora como una especie de apéndice de la competencia material a la que es inherente no arrumba con las exigencias de la reserva de Ley en la materia ni con los principios y los fundamentos del Estado de derecho que establece la Constitución de 1978, en los artículos 9, 14, y 15 a 29 , que aseguran la primacía de la Ley y el derecho a la seguridad, la libertad y la igualdad de todos los ciudadanos, garantizando la existencia de un derecho sancionador común u homogéneo en todo el Estado: no es concebible la existencia de comportamientos y actuaciones prohibidas en unas CCAA y autorizados en otras, o la existencia de regímenes sancionadores tan diversos en la definición de los cuadros de infracciones y sanciones, que establezcan escalas diversas y aún opuestas para la aplicación de las sanciones. En definitiva, no existe una diferencia de sustancia entre los delitos propiamente «penales» y las sanciones administrativas que tienen su raíz en el poder del Estado y su justificación última en la soberanía política que reside en el pueblo del que emanan

29 SSTC 48/1988, de 22 de marzo, FJ. 25; 227/1988, de 29 de noviembre, FJ. 29; 96/1996, de 30 de mayo, FJ. 7).

30 La STC 81/2005 mantiene y actualiza esta doctrina. 
todos los poderes del Estado. La definición de los delitos y sus penas y de toda sanción es una cuestión directamente relacionada con la soberanía y con la representación democrática: es la propia comunidad organizada políticamente la única autorizada para definir delitos e infracciones y sus correspondientes penas y sanciones. ${ }^{31}$

La fuerza expansiva de los derechos fundamentales y de las libertades públicas, ${ }^{32}$ que aparecen enmarcados y presididos por el derecho a la igualdad y por la prohibición de toda discriminación en el artículo 14 CE, constituyen la razón y el verdadero sostén de la atribución competencial a favor del Estado para la regulación de las condiciones básicas que garanticen la igualdad de todos los españoles en el ejercicio de los derechos y en el cumplimiento de los deberes constitucionales en el artículo 149.1.1. ${ }^{a} \mathrm{CE}^{33}$, y en los siguientes apartados todas las competencias que los estados compuestos reservan al estado central. Este poder de regulación es un verdadero plus competencial que preside todo el sistema constitucional de reparto competencial que se fundamenta en las «bases», «condiciones básicas», «normas básicas» o «leyes de bases» que los distintos números del artículo 149.1, reservan al Estado, y el desarrollo de tales bases a las $\mathrm{CCAA}^{34}$. La interacción de los principios normativos contenidos en las «bases» estatales de las distintas materias del artículo 149.1. CE, y la definición de las condiciones que garanticen la igualdad de todos los españoles en el cumplimiento de los deberes constitucionales, delimitará las competencias legislativas de las CCAA en materia sancionadora. Así lo ha establecido la doctrina constitucional con meridiana claridad en la S 87/85, de 16 de julio, FJ 8: «y no introducir divergencias irrazonables y desproporcionadas al fin perseguido respecto del régimen jurídico aplicable en otras partes del territorio» y en las más recientes SS 196/96, FJ 3 y 157/2004, de 23 de septiembre FJ 15, que reiteran y actualizan la doctrina consolidada en la S 227/88, que limita en los aspectos mate-

31 Antonio CANO MATA «Potestad Normativa Sancionadora de las Comunidades Autónomas» RAP, num. 119, mayo agosto de 1989 (CEPC) MADRID.

32 No puede olvidarse el régimen especial de protección del artículo 14 y de los derechos y libertades reconocida en la sección primera del capítulo $2 .^{\circ}$ del Titulo $1 .^{\circ}$, artículo 15 a 29 y $30 \mathrm{CE}$, en el artículo 53 del mismo Título, que garantizan un procedimiento especial sumario de protección judicial y un recurso de amparo ante el propio TC, que a pesar de las críticas ha contribuido como ninguna otra pieza a la modernización y actualización de nuestro derecho, en especial en materia de garantías procesales.

33 El único artículo verdaderamente decisivo para el reparto competencial es el 149.1 que, siguiendo el precedente de la Constitución española de 1931 (artículos 13 a 16), establece un sistema de reparto horizontal de competencias con una sola lista que parece tener una clara influencia de los sistemas federales. Las competencias exclusivas solo se asignan cuando se atribuye la materia en bloque. En el resto de los casos, tanto cuando se atribuyen sectores de una materia como un determinado tipo o calidad de potestades, se trata de competencias compartidas, entre las que destacan, por su número e importancia, las que reservan al Estado la competencia legislativa para establecer las bases o la legislación básica de una materia, y autorizan un desarrollo normativo por las CCAA que así lo asuman en sus respectivos estatutos.

34 E. GARCía DE ENTERRÍA «Curso de Derecho Administrativo» 1990 5. a Edición, página 302. Ed. Cívitas, Madrid, las denomina competencias concurrentes, que suponen una aplicación efectiva de las técnicas de cooperación del Federalismo Cooperativo. 
riales o sustantivos la libertad de configuración de las regulaciones de las infracciones y sanciones de las Comunidades Autónomas al respeto de los principios básicos del ordenamiento estatal y, en todo caso, a lo dispuesto en el art. 149.1.1 CE. En los aspectos procesales o adjetivos, habrán de ajustar su procedimiento sancionador al «administrativo común», cuya configuración es de competencia estatal (art. 149.1.18 CE), sin que ello implique que toda regulación del derecho administrativo sancionador, por el hecho de afectar al ámbito de los derechos fundamentales, sea competencia exclusiva del Estado.

Los artículos 25 y 149.1.1. a CE delimitan y encauzan las competencias normativas de las CCA, que tienen plena libertad para aprobar leyes y reglamentaciones administrativas sancionadoras, siempre que tengan competencia sustantiva sobre la materia sustantiva de que se trate, y que tales disposiciones se acomoden a las garantías constitucionales dispuestas en este ámbito del derecho sancionador (art. 25.1 CE, básicamente), y no introduzcan divergencias irrazonables y desproporcionadas al fin perseguido respecto del régimen jurídico aplicable en otras partes del territorio. El derecho administrativo sancionador creado por las Comunidades Autónomas afectará al ámbito de los derechos fundamentales, pues la previsión de ilícitos administrativos supone siempre una delimitación negativa del ámbito de libre ejercicio del derecho. La naturaleza esencialmente política de la autonomía territorial de unos entes que comparten el poder normativo con el Estado central así lo impone necesariamente ${ }^{35}$. No obstante, las normas sancionadora autonómicas habrán de atenerse a lo dispuesto en el art. 149.1.1 CE, de modo que no podrán introducir tipos ni prever sanciones que difieran, sin fundamento razonable, de los ya recogidos en la normación válida para todo el territorio, y se atenderán al «administrativo común ${ }^{36}$, dentro de estos límites y condiciones, las normas autonómicas podrán desarrollar los principios básicos del ordenamiento sancionador estatal, llegando a modular tipos y sanciones en el marco ya señalado-, porque esta posibilidad es inseparable de las exigencias de prudencia o de oportunidad, que pueden variar en los distintos ámbitos territoriales. Sin perjuicio de resultar desplazadas (artículo 149.3 CE) por la formulación de unas nuevas bases o condiciones básicas estatales $^{37}$.

\footnotetext{
35 Una parte de la doctrina ha visto en la existencia de estos dos ordenamientos separados y unidos en el vértice constitucional, que también reparte los distintos papeles que corresponden al Estatal y a los Comunitarios, la conocida llamada doctrina de los «tres grados» establecida por Kelsen y Nawiasky para explicar el Estado Federal, que no estaría conformado por dos niveles de poder, sino por tres el de los Estados miembros (Gliedstaaten) el del Estado superior (Oberstaat) y el del Estado global (Gesamtstaat), que se superpondría a los otros dos como un nivel propio.

36 De exclusiva competencia estatal (art. 149.1.18 CE).

37 María José Alonso MAS: La prevalencia del derecho del Estado y la inaplicación judicial de las leyes autonómicas: el caso de las cesiones de aprovechamiento en suelo urbano.» RAP, NUM. 16,1 mayo-agosto, 2003. CEPC Madrid.
} 


\section{PODER SANCIONADOR, RESERVA DE LEY Y CORPORACIONES LOCALES}

La aplicación de la doctrina de la doble garantía del artículo 25 de la CE sobre las competencias y la naturaleza de las normas de las corporaciones locales, que no comparten poder normativo con el Estado y carecen de la libertad de configuración que concede el poder legislativo de las CCAA, les privará de toda competencia para autorizar regulaciones o normas sancionadoras propias. Se corta así con una tradición típicamente local para la imposición de sanciones de policía y buen gobierno con origen en la Constitución de Cádiz, que autorizaba a los Ayuntamientos para sancionar las faltas leves y remitir al juez las actuaciones. Consolidándose a lo largo de todo el S. XIX, y sobre todo en el $\mathrm{XX}$, a partir de la dictadura de Primo de Rivera, un poder sancionador local en materia de orden público o policía general de seguridad compartido con el Gobernador Civil que se mantiene durante la Segunda República y a lo largo de toda la dictadura franquista. ${ }^{38} \mathrm{La}$ falta de una teoría sobre el valor normativo de las ordenanzas locales y su consideración de meros reglamentos significa terminar con la supuesta potestad sancionadora local que el artículo 4 de la Ley 7/85, de 2 de abril, de Bases de Régimen del Régimen Local (LBRL) atribuye a las EELL, que se verán así imposibilitadas para regular infracciones y establecer cuadros de sanciones con independencia de la Ley del Estado o de las CCAA, sin cuya cobertura no es posible ni siquiera en aquellas materias para las que la propia LBRL declara como servicios mínimos, como reservados o de obligatoria prestación por los entes locales; menos aún las tradicionales Ordenanzas Generales de Policía y Buen Gobierno o, simplemente, de Policía Urbana, al resultar imposible encontrar hoy leyes sectoriales que presten cobertura a la mayoría de sus numerosas prohibiciones ${ }^{39}$. Será necesario un verdadero pacto de todas las fuerzas políticas (el denominado Pacto Local de 1999) para que, en el marco de las Mediadas para el Desarrollo del Gobierno Local, se diera nueva redacción al artículo 29.2 de la Ley 1/92, Orgánica de Seguridad Ciudadana, para que hubiera una cobertura mínima a algún tipo de sanción de policía general u orden público a las Corporaciones locales.

De acuerdo con esta doctrina se anularán todas las ordenanzas locales en materia sancionadora, casi por el mero hecho de recurrirse, como lo demuestra el examen de la jurisprudencia del TS ${ }^{40}$, entre otras, la STS, de 25 de mayo de 1993, F 13. ${ }^{\circ}$, que anula las disposiciones sancionadoras de la Ordenanza de Espectáculos Públicos del Ayuntamiento de Barcelona, por entender: «El Ayuntamiento

\footnotetext{
38 E. G. DE ENTERríA, T. R. FEnÁNDEZ RodríGUEZ «Curso de Derecho Administrativo» T.2 pag. 157, Ed. Civitas, 1982 MADRID.

39 Ramón Martín Mateo y F. Sosa Wagner. Op. cit. 12.

40 Enrique SÁNCHEZ GOYANES «La reconstrucción jurisprudencial de la potestad normativa sancionadora de las CCLL (acotaciones a la STS, 29-09-03) Diario La Ley, n . 5918, 22-12-2003. Ed. La Ley, Las Rozas, MADRID.
} 
autor de la Ordenanza no aduce ante este Tribunal las Leyes sectoriales a cuyo amparo hubiese obrado para hacer la tipificación de las conductas infractoras y para informar las sanciones a ellas correspondientes... y, aunque, en este ámbito, la reserva de Ley sólo tenga una eficacia relativa en el sentido de permitir un mayor margen de actuación, esa relativización no puede conducir a admitir como conformes con el principio de reserva de Ley las regulaciones reglamentarias independientes y no claramente subordinadas a la Ley (STC 83/1990)». La STS de 12 de junio de 1993, que anula la Ordenanza General de Publicidad del Ayuntamiento de Getafe (Madrid), al razonar que: «incluso en las competencias que le aparecen atribuidas al Municipio, habrá de acomodarse a los términos fijados en la legislación del Estado y de las Comunidades Autónomas; lo contrario sería desconocer el principio de jerarquía normativa, consagrado en el art. 9.3 CE.» Lo que viene a recordar el carácter bifronte del Régimen Local y el limitado concepto de la autonomía local del TC y del TS, que sostienen una interpretación restrictiva del contenido de la garantía institucional de la Administración Local, que desde luego no incluye como nota indispensable para su reconocimiento la competencia para definir regímenes sancionadores propios; al contrario, su régimen competencial es por completo tributario de la asignación de competencias por la legislación sectorial administrativa o directamente por las bases normativas que apruebe el Estado al amparo de los distintos ordinales de artículo 149.1 CE. La misma doctrina y similares razonamientos laten en la STS de 6 de noviembre de 1995, que anula la Ordenanza Sancionadora del Consumo de Drogas en Lugares Públicos de Sevilla de 1992, por la entonces falta de cobertura de la Ley 1/1992, Orgánica de Protección de la Seguridad Ciudadana.

En definitiva, se trate de ordenanzas de Policía General o de tutela sectorial, sin la previa atribución competencial por una Ley de cobertura del Estado o de las CCAA, los EELL carecen de potestades para regular infracciones y sanciones. Incluso cuando se trate de servicios tradicionalmente locales - mínimos, reservados obligatorios -, carecerán de competencias sancionadoras, salvo atribución legal específica, como es el caso de la Ley de Seguridad Vial, que presta cobertura para una serie de supuestos característicos de infracciones municipales en esta materia de tráfico viario. Lo que ha posibilitado la existencia de un régimen sancionador municipal, que vía modelos tipo de ordenanza, establecidos hoy por la FEMP, ha facilitado una formulación homogénea por todo el territorio de España, que ha evitado la aprobación de sanciones de muy distinta cuantía e importe para los mismos injustos. Cuestión no menor, al estar en juego uno de los principios y valores fundamentales del Estado de Derecho como es el de la igualdad ante la Ley. El alcance de esta doctrina restrictiva implica que también carecen de la necesaria cobertura legal las ordenanzas locales en materia medioambiental y para la protección de los consumidores, resultando ilegales la práctica totalidad de las reglamentaciones municipales dirigidas a la reducción de los niveles de emisión de ruidos y su correlativo régimen sancionador, hasta la aprobación de la 37/2003, conocida como Ley del Ruido, que tampoco es generosa con el poder sancionador local. Sin que pudiera tener 
cobertura en la Ley de 1972 de Protección del Ambiente Atmosférico, y sin que el Reglamento de Actividades Molestas, Insalubres, Nocivas y Peligrosas, de 1961 pueda otorgarla (STS de 6 de febrero de 1996, FD 6. ${ }^{\circ}$ ), a pesar de tratarse de una norma preconstitucional; en definitiva, la práctica totalidad de las sanciones municipales no autorizadas o predeterminadas directamente por una Ley del Estado o de la Comunidad Autónoma, incluidos los abastos y venta de alimentos, quedando en tela de juicio hasta las tradicionales sanciones reguladas en las Ordenanzas Reguladoras de Aprovechamientos Comunales ${ }^{41}$.

\section{NECESARIA NATURALEZA POLÍTICA DE LA AUTONOMÍA LOCAL}

La doctrina constitucional y la practica judicial consolidaron una situación curiosa en la que teniendo las Corporaciones Locales atribuida la competencia y potestad sobre determinadas materias, no pueden definir el régimen sancionador destinado a posibilitar su cumplimiento» (STS de 6 de febrero de 1996, fundamento $\left.7 .^{\circ}\right)$. Situación que, según el propio TS, sólo podrá superarse cuanta más diligencia empleen tanto el legislador estatal como el autonómico destinados a materializar el ámbito concreto de la autonomía municipal y provincial y que en el fondo es el reflejo a de las propias carencias de la doctrina constitucional de la autonomía local en la $\mathrm{CE}^{42}$ y del sistema de atribución competencial general a laos entes locales, que como advirtió Santamaría Pastor ${ }^{43}$ padece las carencias de una regulación que se inclinaba por definir negando: las competencias locales serían aquellas que el legislador estatal y autonómico decidieran que fueran con el único límite de no desfigurar la institución hasta hacerla socialmente irreconocible. La falta de un marco competencial mínimamente definido constituye la esencia del problema. Las competencias que exige el ejercicio de la autonomía local están definidas en negativo: por un límite negativo que no se puede sobrepasar, por lo que no debe $\operatorname{ser}^{44}$. Ni la CE ni la LBRL establecen un listado de competencias locales de tal manera que la autonomía local puede tener muy diversos contenidos legales ${ }^{45}$. El artículo 25 de la LBL se limita establecer

\footnotetext{
41 SSTS de 20 de mayo de 1992: «pues también específicamente con relación a ellas se ha dicho que, aun teniendo las respectivas Corporaciones margen de capacidad reglamentaria, ello es cosa distinta de que sobrepasen el modo como ha delimitado la Ley la esfera jurídica de los particulares, definiendo los derechos subjetivos y los deberes y los requisitos necesarios para ser titulares de aquéllos».

42 FANLO LORAS Antonio «Fundamentos constitucionales de la autonomía local» CEC, 1992, MADRID

43 Notas sobre la Sentencia de las Diputaciones Provinciales REDA, num. 34, 1982, MADRID

44 F. CAAMAÑO: «Autonomía Local y Constitución» REDC, num. 70, enero abril 2004.

45 Así lo entiende el TC STC 170//89 F 9 «Más allá de este límite de contenido mínimo que protege la garantía institucional la autonomía local «es un concepto jurídico de contenido legal, que permite configuraciones legales diversas, válidas en cuanto respeten aquella garantía institucional. Por tanto en relación con el juicio de constitucionalidad sólo cabe comprobar si el legislador ha respetado esa garantía institucional». Y S 159/2001: «la autonomía local consagrada en el art. 137 CE (con el complemento de los arts. 140 y 141 CE)
} 
una serie de materias de interés local, determinación indirecta o en negativo en parte culpable del proceso de vaciamiento competencial denunciado por la doctrina ${ }^{46}$. Los efectos de aquella configuración de la autonomía local en una materia como la sancionadora que está presidida por el principio de reserva de ley fueron catastróficos: las entidades locales carecen de competencias para definir un régimen sancionador propio. Lo que implica la existencia de todo un régimen competencial devaluado, al carecer de uno de los atributos propios del régimen administrativo como es el de contar con una potestad sancionadora funcional y necesaria para el buen ejercicio de las competencias materiales. Sin la posibilidad de sancionar los incumplimientos de los mandatos legislativos, mediante la imposición de sanciones a los autores, las entidades locales se ven privadas de un poder normativo completo, al carecer de competencia para aprobar sanciones en los casos de incumplimiento. Queda así muy mermado el respeto al ejercicio de la autoridad democráticamente legitimada, con grave quebranto de los derechos subjetivos e intereses del resto de los ciudadanos. Y quedaba sin resolver la tensión entre autonomía política municipal y el régimen de protección de los derechos fundamentales, al no existir una fórmula que posibilitase la más mínima afectación por reglamentación local.

En resumen, la doctrina constitucional no asume un concepto de autonomía local que, como en el caso de las CCAA, incluya un concepto funcional de la competencia sancionadora o, en palabras del dictamen del Consejo de Estado 1749/1994, que entiende inherente a la titularidad de la competencia la posibilidad de establecer sanciones: «La potestad sancionadora para asegurar la eficacia real de las Ordenanzas es inherente o implícita a la potestad de la Ordenanza, según la mejor doctrina sobre los poderes implícitos o inherentes.» El razonamiento del Consejo de Estado parte de la necesidad de aceptar un concepto flexible de la reserva de ley también en esta materia sancionadora regulada por ordenanza local, que el propio TC acepta sin ambages en las denominadas situaciones o relaciones de sujeción especial: colegios profesionales; sentencia del Tribunal Constitucional de 21 de diciembre de 1989, matizada por la de 11 de junio de 1992, o el caso de las relaciones de sujeción especial «respecto de las cuales se admite una capacidad administrativa de autoordenación que las distingue del «ius puniendi» del Estado» STC, 21de enero de 1987», menos problemas debe tener la aceptación de un poder sancionador local en manos de unas autoridades democráticamente elegidas.

El dictamen del Consejo de Estado identifica competencia sancionadora con autonomía local, si los entes locales regidos por el principio democrático para el gobierno y administración de los Ayuntamientos no tienen competencia para

\footnotetext{
se traduce en una garantía institucional de los elementos esenciales o del núcleo primario del autogobierno de los entes locales territoriales, núcleo que debe necesariamente ser respetado por el legislador (estatal o autonómico, general o sectorial) para que dichas Administraciones sean reconocibles en tanto que entes dotados de autogobierno.
}

46 Ramón Martín Mateo y F. Sosa Wagner Op. cit. 12. 
establecer ordenanzas sancionadoras que no sean un mero reflejo y un desarrollo meramente complementario de una Ley, verán muy limitada su autonomía política garantizada por la $\mathrm{CE}^{47}$. En otro caso, las reglamentaciones locales no gozarán de la imperatividad que se presume del mandato normativo legítimo: «encierran, en su misma potencialidad, un deber de inexcusable cumplimiento y obediencia, así como una previsión de reacción jurídica en caso de incumplimiento», quedando reducidas a meras declaraciones de intenciones. Asume el Consejo de Estado en este dictamen un concepto funcional o adjetivo de la potestad sancionadora, que más que fundarse en la ley queda limitado por las leyes, de tal manera que las potestades sancionadoras locales se deben entender incluidas en la garantía institucional de la Administración Local, en el genuino sentido de protección de la entidad en términos reconocibles, como fuera formulada por Carl Schmitt. ${ }^{48} \mathrm{Al}$ contrario que el Tribunal Constitucional, entiende factible una flexibilización más intensa de la reserva de ley en materia sancionadora siempre «que no se oponga a la Ley» y siempre «que las ordenanzas cumplan las exigencias de legalidad», tal como establecían los artículos 49 de la Ley 7/85, de 2 de abril (LBRL), 55 y 59 del DL 781/86, de 18 de abril, TRRL. El alto órgano consultivo propone un concepto funcional de la competencia sancionadora local que entiende incluido en la autonomía local constitucionalmente garantizada con fundamento en el cumplimiento del principio democrático y del concepto de la Ley como autodisposición de la comunidad sobre sí misma y, desde luego, como expresión de la voluntad popular. ${ }^{49}$

\section{NUEVAS PROPUESTAS DOCTRINALES}

Las denunciadas limitaciones de la teoría de la garantía institucional favorecieron la búsqueda de una interpretación constitucional que supere estas limita-

\footnotetext{
47 «.. hay que convenir que la potestad sancionadora tiene su pleno reconocimiento en la Ley y sus límites en la misma, y es expresión de la autonomía municipal y de la legitimidad democrática municipal, siempre que no se oponga a la Ley y que las ordenanzas cumplan las exigencias de legalidad, de modo que para asegurar la efectividad de la Ordenanza, dentro de la competencia municipal, pueden tipificar infracciones y sanciones, aunque no sean ejecución o desarrollo de una ley», dado que en otro caso no «existiría esta autonomía (la local) si... se negase la potestad de normar y sancionar que en general se reconoce a dichos entes (los municipales)».

48 «consiste técnicamente en la garantía objetiva de la presencia y la actuación permanentes de la institución en el ordenamiento del Estado en su conjunto, es decir, en una garantía institucional, en la forma y manera en que se definió para el reconocimiento y defensa de la autonomía local en el artículo 127 de la Constitución alemana de Weimar, de 11 de agosto de 1919: La Constitución puede otorgar una protección especial a determinadas instituciones con el fin de hacer imposible su supresión por el legislador. El artículo 127 de la Constitución de Weimar, al consagrar el derecho a la autonomía de municipios y regiones lo que garantiza en realidad era la propia institución y todas las leyes que por su contenido material la supriman o la priven de su contenido esencial son inconstitucionales

49 Juan Ingancio GOMAR SÁNCHEZ: «La regulación de la potestad sancionadora local, requisito imprescindible para una segunda y auténtica descentralización» EL CONSULTOR, n . 9 , mayo de 2003, Editorial LA LEY. Las Rozas, MADRID.
} 
ciones y servidumbres para configurar una verdadera y auténtica garantía constitucional de la autonomía local. Las propuestas de revisión de la teoría de la garantía institucional se proponen por la doctrina administrativa y constitucional con un contenido más extenso del interés local que la mera garantía de pervivencia o continuidad de los entes locales, en el que deben entenderse incluidos sus caracteres y competencias básicas, presidido todo ello por el principio democrático. Para estos autores, si la Constitución no enumera competencias locales no por ello entrega la autonomía local en blanco al legislador para que la dibuje discrecionalmente. Cuando se trata de atribuir competencias a los entes locales, la ley no puede actuar como un necesario y previo trámite que ahogue el normal ejercicio del Gobierno Local. Desde este punto de vista, para no sacrificar la existencia de las potestades normativas locales, proponen una modulación o flexibilización del principio de reserva de ley, especialmente, en materias fiscal y sancionadora, en las que la «interpositio legis» resulta de la aplicación directa de los artículos 25 y 133 de la CE, para posibilitar el juego de una reglamentación local autónoma, que implica una especie de vinculación negativa de unas competencias legislativas originarias e irrenunciables de las Entidades Locales.

Estas tesis, amén de revivir la discusión sobre el mundo local en España, son el verdadero sustento de la denominada segunda descentralización a favor de los entes locales ${ }^{50}$. No sólo han tenido una gran repercusión doctrinal; sus efectos pueden verse en la doctrina constitucional, S 233/99, que reconoce la plena naturaleza democrático-representativa de las ordenanzas fiscales, al aprobarse por el Pleno, representación democrática y «soberana» de los ciudadanos del municipio, lo que confiere a sus ordenanzas valor superior a los reglamentos de las $\mathrm{CCAA}^{51} \mathrm{y}$, con mayor trascendencia, en la doctrina sentada en la S 132/2001

\footnotetext{
50 Defienden esa naturaleza política, según afirma CAAMAÑO: A. FANLO LORAS, Fundamentos constitucionales de la autonomía local. El control sobre las corporaciones locales; el funcionamiento del modelo constitucional de autonomía local, CEC, Madrid, 1990; E. MARTín MATEO y F. SOSA WAGNER, «Cincuenta años en la Administración local» RAP, núm. 150, 1999; L. PAREJO ALFONSO, «El régimen jurídico de la Administración local hoy»; J. L. CARRO FERNÁNDEZ-VALMAYOR, «El debate sobre la autonomía municipal» núm. 147 RAP, 1998, págs. 61 y ss; E. SÁNCHEZ GOYANES, La potestad normativa del municipio español. Ordenanzas, reglamentos, planes urbanísticos, normas, El Consultor, Madrid, 2000; J. GARCÍA MoRRILLO, La configuración constitucional de la autonomía local, Madrid, 1996; Tomás FONT i LLOVET, «La renovación del poder local: Avances en la configuración jurídica e institucional del gobierno local», págs. 13-39, y L. ORTEGA, «La potestad normativa local», págs. 39-55, en Anuario del Gobierno Local 2001, Madrid; E. AJA, «Configuración constitucional de la autonomía local», en Informe sobre el gobierno local (Tomás FONT, dir.), MAP y Fundación Pi i Sunyer, Madrid, 1992; J. GARCíA RoCA, «El concepto actual de autonomía local según el bloque de la constitucionalidad», REALA, NÚM. 282, 2000.
}

51 STC 233/99, de 13 de diciembre, sobre la LRHL el ámbito de colaboración normativa de los Municipios, en relación con los tributos locales, era mayor que el que podría relegarse a la normativa reglamentaria estatal. Dos datos normativos consideramos entonces relevantes para llegar a aquella conclusión: que las ordenanzas municipales se aprueban por un órgano - el Pleno del Ayuntamiento - de carácter representativo (art. 22.2.d de la LBRL, y que la garantía local de la autonomía local (arts. 137 y 140 CE) impide que la ley contenga una regulación agotadora de una materia - como los tributos locales - donde está claramente presente el interés local. F. 10 c), concluimos que aquella concepción flexible de la reserva de ley tributaria -en relación con las ordenanzas fiscales - no toleraba la renuncia de la ley a todo encuadramiento normativo de la potestad tributaria local. 
F.V., que autoriza, igual que en materia fiscal, una formulación flexible del principio de reserva de ley para la tipificación de infracciones y sanciones en materias donde, por estar presente el interés local, existe un amplio campo para la regulación municipal, siempre que la regulación local la apruebe el Pleno del Ayuntamiento ${ }^{52}$. Sin que sea necesario la previa definición de cada tipo o ilícito por la Ley, es suficiente una habilitación legislativa que establezca los principios generales. Es claro que el TC asumió en parte las propuestas de flexibilización de esta corriente doctrinal, que implican un mayor alcance explícito del interés local, que aquí sí identifica una competencia para regular sus tributos propios y para imponer sanciones en sus materias tradicionales con una mayor flexibilización de la reserva de Ley, pero sin asumir una vinculación negativa de la ordenanza municipal ni en estos aspectos esenciales ni en otros ámbitos competenciales. No se aceptan, desde luego, las propuestas de un municipalismo «soberanista» ${ }^{53}$, para el que la Constitución atribuye un espacio en blanco a favor de los Ayuntamientos. Lo que chocaría directamente contra el principio de reserva de Ley, remitiéndonos a una vuelta al medievalismo anunciada por Alain Ming ${ }^{54}$, un nuevo Sacro Imperio Romano Germánico que puede verse en la construcción de la Unión Europea, integrando hoy como entonces, por estados, ciudades, redes, regiones, länders, y todas las regiones y naciones de la vieja Europa buscando el reconocimiento de un poder originario y previo al Estado para construir la Unión desde las raíces de todos los pueblos europeos. Aunque resulta innegable en la nueva doctrina constitucional la plena aceptación de la naturaleza político representativa del Gobierno Local que establece el artículo 140 de la CE, y reconoce abiertamente la Carta Europea de la Administración Local.

$\mathrm{Al}$ final, el TC asume en su doctrina las propuestas doctrinales favorables a una consideración política y democrática de los gobiernos locales, que pueden establecer reglamentaciones sancionadoras innovativas en aquellas materias de claro interés local y siempre que una ley haya señalado los criterios generales, sin llegar a definir los tipos concretos de las sanciones a establecer. De tal manera que, sin renunciar por completo a la necesidad de una previa norma con rango formal de ley «interpositio legis», la reserva de Ley en materia sancionadora local queda limitada a definir criterios generales, en los

\footnotetext{
52 Esta flexibilidad no sirve, con todo, para excluir de forma tajante la exigencia de ley. Y ello porque la mera atribución por ley de competencias a los Municipios — conforme a la exigencia del art. 25.2 LBRL_ no contiene en sí la autorización para que cada Municipio tipifique por completo y según su propio criterio las infracciones y sanciones administrativas en aquellas materias atribuidas a su competencia. No hay correspondencia, por tanto, entre la facultad de regulación de un ámbito material de interés local y el poder para establecer cuándo y cómo el incumplimiento de una obligación impuesta por Ordenanza Municipal puede o debe ser castigada. La flexibilidad alcanza al punto de no ser exigible una definición de cada tipo de ilícito y sanción en la ley, pero no permite la inhibición del legislador.

53 José Ramón PARADA VAZQUEZ: «La segunda descentralización del Estado Autonómico al Municipal», pags. 31 y ss. RAP, num. 172, enero-abril de 2007, (CEPC) MADRID.
}

54 «La Nueva Edad Media. El Gran vacío Ideológico». Temas de hoy, MADRID, 1993. 
ámbitos materiales de competencias garantizadas constitucionalmente, que hay que identificar con el listado del artículo 25.2 de la LBRL y con la regulación de los servicios declarados mínimos y obligatorios por la misma Ley. Se acepta así un cierto poder normativo local fundamentado en el principio democrático, reclamado por la doctrina para autorizar una mínima autodisposición de la comunidad sobre sí misma. El poder sancionador de los entes locales está condicionado a la previa definición por ley de los principios generales de las sanciones a establecer - limitado a los ámbitos de manifiesto interés local-, en una regulación aprobada por el Pleno. Su fundamento último y definitivo reside en el principio democrático que rige su composición y legitima su actuación política y su reconocimiento efectivo quizá se deba a razones de prudencia o de oportunidad que pueden variar en los distintos ámbitos de ordenación territoriales - STC 87/1985, de 16 de julio F 9-, y que sólo hasta la consolidación política del denominado pacto local, suscrito por todos los partidos políticos con representación parlamentaria en el año 1999, - modificó sustancialmente la LBRRL para posibilitar el acceso de los entes locales al TC en defensa de la autonomía local y una serie importante de leyes, entre otras la Ley Orgánica 1/92, de Seguridad Ciudadana, para atribuir, precisamente, mayores competencias sancionadoras a las ordenanzas locales - se han tomado en consideración por el TC para asumir un poder sancionador local.

En definitiva, sin la existencia de una norma de cobertura que defina las conductas básicas y el cuadro general de sanciones a imponer, la Administración carece de competencias para regular y establecer sanciones. La doctrina constitucional vigente veda la existencia del reglamento independiente y autónomo en materia sancionadora, puede decirse que no existen ni pueden existir esos poderes sancionadores inherentes a la competencia material de la Administración para dirigir la acción política ${ }^{55}$. La asunción de competencias vía Estatutos de Autonomía o el reconocimiento de una autonomía verdaderamente política de las EELL, junto con la definición de un concepto amplio de la garantía institucional o constitucional de la Administración Local y la atribución real y efectiva de competencias de ordenación y gestión de ámbitos de la actividad administrativa, o la asignación de servicios mínimos u obligatorios, no atribuye por sí sola competencia para el establecimiento de sanciones. No existen en definitiva poderes inherentes a las competencias materiales para regular y establecer ilícitos administrativos sin una previa habilitación legal que permita una definición administrativa de las infracciones y sus correspondientes sanciones, aunque tal habilitación sea limitada al mínimo posible, resulta exigible.

55 STC 305/93: «El art. 25 CE obliga al legislador a regular por sí mismo los tipos de infracción administrativa y las sanciones correspondientes en la medida necesaria para dar cumplimiento a la reserva de Ley, sin que sea posible que, a partir de la Constitución, se puedan tipificar nuevas infracciones ni introducir nuevas sanciones o alterar el cuadro de las existentes por una Norma reglamentaria cuyo contenido no esté suficientemente predeterminado o delimitado por otra Norma de rango legal». 


\section{LA STC 132, 2001, DE 8 DE JUNIO}

El TC formula en la S 233/99 una interpretación integradora de los principios constitucionales de reserva de Ley en materia tributaria «versus» autonomía local garantizada en la CE, con expreso reconocimiento de la necesaria reserva de un papel necesario e importante de los entes locales en la definición última de la carga tributaria, y con fundamento último en la naturaleza democrática del Pleno. Entiende que la elección directa de los concejales permite establecer un paralelo entre la Ley del Estado o de las CCAA y las normas municipales, como verdadera expresión de la voluntad general y como autonomarción ${ }^{56}$, para concluir que las ordenanzas locales, por esa cualidad democrática, en cuanto expresión directa de la voluntad vecinal, no son equiparables a la potestad reglamentaria de la administración - no desarrollan leyes - y son la expresión de la autonomía local constitucionalmente garantizada. Quedaba pendiente establecer una solución sobre el alcance de la autonomía local en materia sancionadora que, al igual que en materia fiscal, determinase el alcance de la autonomía local. Teniendo en cuenta la especial rigidez de la reserva de Ley en materia sancionadora, al estar directamente afectados los principios de igualdad, de presunción de inocencia, el derecho a no declarar contra sí mismo, el habeas corpus, el principio pro accione; en fin, la obligada igualdad real de los ciudadanos ante la Ley ${ }^{57}$, que reclaman la previa intervención de la Ley en el establecimiento y definición de todo tipo de infracciones o delitos y sus correspondientes penas o sanciones, dificulta notablemente la delimitación de un campo normativo para la Ordenanza sancionadora local. Sin que, por otro lado, los reglamentos estatales o de las CCAA puedan excluir, cuando se trate de materias de interés local, un poder normativo local, fundado en su autonomía política para aprobar sino una ordenación sancionadora independiente, al menos un desarrollo normativo propio. Lo contrario implicaría una vulneración de la autonomía local garantizada.

En el recurso de amparo resuelto por la decisiva S 132/2001, quizá por entender que existía ya una conciencia política unánime a una interpretación favorable al reconocimiento de un mínimo poder sancionador local, necesario

56 STC 233/99 (FF. 10 y 18). Expresamente dijimos entonces que el ámbito de colaboración normativa de los Municipios, en relación con los tributos locales, era mayor que el que podría relegarse a la normativa reglamentaria estatal. Dos datos normativos consideramos entonces relevantes para llegar a aquella conclusión: que las ordenanzas municipales se aprueban por un órgano -el Pleno del Ayuntamiento - de carácter representativo (art. 22.2.d de la LBRL); y que la garantía de la autonomía local (arts. 137 y $140 \mathrm{CE}$ ) impide que la ley contenga una regulación agotadora de una materia - como los tributos locales - donde está claramente presente el interés local. Con todo, una concepción flexible de la reserva de ley tributaria - en relación con las ordenanzas fiscales - no toleraba la renuncia de la ley a todo encuadramiento normativo de la potestad tributaria local.

57 El art. 25.1 CE obliga al legislador a regular por sí mismo los tipos de infracción administrativa y las sanciones que le sean de aplicación, sin que sea posible que, a partir de la Constitución, se puedan tipificar nuevas infracciones ni introducir nuevas sanciones o alterar el cuadro de las existentes por una norma reglamentaria cuyo contenido no esté suficientemente predeterminado o delimitado por otra con rango de Ley. 
e imprescindible para salvaguardar el ejercicio normal de las competencias locales y para obtener el necesario reconocimiento y respeto ciudadano; para evitar, en definitiva, la continua degradación de un poder municipal impotente en materia de seguridad general, el TC aborda la relación entre las leyes y las ordenanzas locales en busca de campo para la colaboración normativa. El mero planteamiento de la necesidad de una presencia local, en materia sancionadora, implica ya un reconocimiento implícito de la posibilidad de un papel municipal en la regulación de las infracciones y sanciones en asuntos o materias de interés local. Sin embargo, el TC no establece distinción entre aquellas materias en las deberán ejercer competencias de acuerdo con las leyes de aquellas que se entiende directamente protegidas por la garantía institucional de la administración local. En definitiva, no toma en consideración, a los efectos de reconocer una mayor o menor extensión e intensidad de una potestad sancionadora local propia, la distinta naturaleza de las materias que enumera el artículo 25.2 de la LBRL, en las que muy pocas gozan de garantía institucional. ${ }^{58}$

\subsection{Diferente finalidad de la reserva de ley en materia penal y fiscal}

La naturaleza político democrática de las ordenanzas locales no permite una identificación negativa general del alcance de la reserva de Ley; además la reserva legislativa penal del art. 25.1 CE es más estricta que la reserva que incorporan para la materia fiscal los artículos 133 y $31 \mathrm{CE}$, que prevén una presencia de los entes locales que no aparece en el artículo 25 CE. Para el TC, la diferencia tiene su fundamento en la distinta funcionalidad de una y otra. En materia fiscal y tributaria debe cumplir con el principio autodispositivo en el establecimiento de los deberes tributarios, contribuir a la preservación de la unidad del ordenamiento y garantizar una básica posición de igualdad de los contribuyentes: SSTC 19/87, de 17 de febrero, FF 19 y 4, y F. 10.c). En materia sancionadora, la reserva de Ley es por excelencia la garantía de la libertad, que es el valor constitucional más preciado ${ }^{59}$, por ende admite menos flexibilización sobre la necesaria posición de igualdad en las distintas relaciones de los ciudadanos con las variadas manifestaciones del poder punitivo del Estado, en el que forzosamente está incluido el poder local y el de las CCAA, que no pueden incidir libremente sobre la esfera de libertad del individuo.

Para la doctrina del TC, la flexibilización de la reserva de Ley penal debe tener menor alcance que en materia fiscal. No pueden coexistir distintas con-

58 (SSTC 109/98 y 11/99), «porque los imperativos constitucionales derivados del art. 137 CE, por un lado, y del 149.1.18 CE, por otro, no son coextensos».

59 PREÁmBULO DE LA CE 78. «La Nación española deseando establecer la justicia y promover el bien de cuantos la integran...». 
cepciones del injusto penal. El principio de autonomía puede garantizar que una Comunidad Autónoma grave una materia con un tributo y otra no lo haga o establezca otro similar pero distinto; en el mismo sentido, posibilita una muy distinta presión fiscal entre los distintos tipos de Ayuntamientos en relación directa con su población y con los servicios que han de prestar o que hayan asumido efectivamente y que vienen a justificar un nivel de calidad en la prestación de servicios y en el gobierno municipal que tendrán sanción político-electoral. Por el contrario, la determinación del injusto y los criterios de la antijuridicidad penal son resistentes a la autonomía territorial local, que no tiene un concepto funcional del poder sancionador como el de las CCAA, que comparten el poder legislativo con el Estado y sólo están condicionadas por el concepto de bases, legislación básica o condiciones básicas de la legislación dictado por el Estado al amparo de los distintos números del artículo 149.1.1. ${ }^{\circ} \mathrm{CE}^{60}$, y que constituye el verdadero núcleo duro de la «territorialización» de la reserva de ley penal, para evitar que unos comportamientos puedan o no ser sancionados y que de serlo, lo sean con distintos criterios de antijuridicidad que terminen por imponer un universo sancionador expansivo sólo sujeto a la tutela y a la valoración objetiva judicial ${ }^{61}$. Desde este punto de vista, la consideración y determinación de las clases e intensidades de injustos tiene un alcance general y abstracto. No es posible aquí establecer distintos criterios o modulaciones de la culpabilidad según tramos de población; por el contrario, el mismo comportamiento injusto podrá ser sancionado con igual intensidad en todos los Ayuntamientos. Los criterios de intensidad deben forzosamente estar referidos a la intensidad de los injustos y tener, por ende, alcance general.

60 J. TORnOS MAS (1991) «La legislación básica en la jurisprudencia del TC.» RVAP, num. 31/91, entiende que las leyes básicas pertenecen al bloque e constitucionalidad en la medida en que configuran el ámbito de la potestad autonómica

61 STC 151/97 F 3, Atendiendo a las exigencias que del principio de legalidad derivan respecto del aplicador y, en especial, respecto del Juez, la presencia de cláusulas normativas necesitadas de valoración judicial obliga a éste a indagar los cánones objetivos que han de regir dicha valoración, atendiendo, en casos como el presente, a los valores generalmente admitidos y conocidos socialmente, depurados desde la perspectiva del ordenamiento jurídico y, especialmente, desde la Constitución.

Todo este proceso de concreción de las cláusulas relativamente indeterminadas a que aludimos, ha de hacerse, según hemos dicho, de modo explícito. El déficit de la ley sólo es compatible con las exigencias del principio de legalidad si el Juez lo colma. Y la única manera de llevar a cabo esta tarea de conformidad con el art. $25 \mathrm{CE}$ es hacer expresas las razones que determinan la antijuricidad material del comportamiento, su tipicidad y cognoscibilidad y los demás elementos que exige la licitud constitucional del castigo. Ello significa que, como sucede en el ámbito de otros derechos fundamentales también la garantía del citado precepto constitucional puede vulnerarse por la ausencia de un adecuado razonamiento que ponga de manifiesto el cumplimiento de sus exigencias.

F 4 En rigor, como hemos expuesto en la reciente STC 137/1997, la garantía de tipicidad que impide que los órganos judiciales puedan sancionar fuera de los supuestos y de los límites que determinan las normas, no es más que el reverso, el complemento y el presupuesto de la garantía de determinación que ha de preservar el legislador y, en su caso, la Administración, con unas «concretas, precisas, claras e inteligibles», STC 34/1996, fundamento jurídio 5.» 


\subsection{Criterios delimitadores del poder sancionador local: la definición del interés local}

El primer criterio de delimitación de la competencia sancionadora local, en la STC 132/2001, está referido al interés local: «En forma similar a como acabamos de recordar en relación con la reserva de ley tributaria, también la exigencia de ley para la tipificación de infracciones y sanciones ha de ser flexible en materias donde, por estar presente el interés local, existe un amplio campo para la regulación municipal y siempre que la regulación local la apruebe el Pleno del Ayuntamiento». El problema queda referido así, en un primero momento, a la determinación de cuáles sean esas materias de interés local. Cuestión de especial dificultad, al no existir previsión constitucional al respecto y quedar referido el sistema competencial local a la Ley. La Sentencia refiere el interés local a los ámbitos materiales definidos por el art. 25.2 de la LBRL, que se limita a señalar las materias en las que forzosamente el legislador estatal o autonómico han de reservar necesariamente alguna competencia a los Entes locales. Quedando al albur de la decisión política que en cada caso defina el interés del Estado o de las CCAA y la participación que corresponda a la Administración Local en el poder político.

En cualquier caso, la expresa referencia de la Sentencias al artículo 25.2 de la LBRL y una lectura de su listado de materias en las que forzosamente han de asumir competencias los entes locales, acota suficientemente los asuntos que pueden entenderse de interés local, incluso directamente enraizables en el artículo 137 de la $\mathrm{CE}$, sin perjuicio de detectarse una vez más en la doctrina constitucional española un concepto subordinado y dependiente de la Administración Local, referido a los aspectos esenciales de la ciudad y a la prestación de los servicios mínimos urbanos, que mantiene el concepto de pouvoir municipal establecido por la Asamblea revolucionaria francesa de 1789, con la dicción que figura en el artículo 49, del Decreto de 14 de diciembre de 1789, «les corps municipeaux auront deux espèces de fonctions á remplir, les unes propres a pouvoir municipal, les autres propres a l'Administratión générales de l'Etat et déléguées par elle aux Municipalités», que concibió un municipio con un poder paternal, vecinal y doméstico, ${ }^{62}$ una administración ajena al Gobierno dirigida a regular sus propios asuntos familiares, al centralizar la Asamblea legislativa la voluntad popular y detentar la soberanía nacional, quedaban perfectamente separado los conceptos de administración y gobierno, quedando excluidos los municipios de la gestión y de toda decisión sobre los grandes asuntos políticos del Estado. Sin que, al menos en los asuntos que el Tribunal considera directamente protegidos por el artículo $137 \mathrm{CE}$, se reconozca una competencia sancionadora funcional, necesaria e inherente al propio concepto de autonomía ${ }^{63}$.

62 Discurso de SAINT JUST ante la Asamblea revolucionaria.

63 La nueva doctrina constitucional inaugurada por la $\mathrm{S}$ 159/2001 y consolidada plenamente en la $\mathrm{S}$ 240/2006, la LBRL sólo servirá como canon de validez en aquellos aspectos enraizables directamente en los arts. 137, 140 y $141 \mathrm{CE}$ : sólo aquellos extremos de la LBRL que se puedan incardinar de forma directa en los 


\subsection{Alcance y contenido de la «interpositio legis»}

Las garantías que incorpora el principio de legalidad penal se oponen a la existencia de un concepto funcional de las competencias sancionadoras locales: la atribución competencial por las leyes sectoriales en las distintas materias no implique la atribución de un poder o de una competencia sancionadora implícita. El TC recuerda en esta S 132/2001 que la mera atribución competencial: «no contiene en sí la autorización para que cada Municipio tipifique por completo y según su propio criterio las infracciones y sanciones administrativas en aquellas materias atribuidas a su competencia. No hay correspondencia, por tanto, entre la facultad de regulación de un ámbito material de interés local y el poder para establecer cuándo y cómo el incumplimiento de una obligación impuesta por Ordenanza Municipal puede o debe ser castigada», lo que descarta de plano cualquier veleidad sobre la posible existencia de una vinculación negativa de la ordenanza sancionadora local de la ley formal, aunque se trate del núcleo indeclinable de competencias locales y la regulación local no se oponga a lo dispuesto en las leyes. No se reconoce la pretendida por la doctrina científica y por una parte de la doctrina del TS vinculación negativa de la ordenanza local en el sentido establecido por los artículos 55 y 59 del DL 781/86, Texto Refundido de las Disposiciones Legales Vigentes en Régimen Local (TRRL) de no contender preceptos opuestos a las leyes, y la definición de unos umbrales para las multas ${ }^{64}$ según índices de población de cada municipio, con fundamento directo en la Carta Europea de la Autonomía Local ${ }^{65}$ y en la propia autonomía

artículos 137, 140 y $141 \mathrm{CE}$, de cuyo contenido no representen más que exteriorizaciones o manifestaciones, dice el TC - forman parte de la autonomía local constitucionalmente garantizada, mientras que los que se refieran a aspectos secundarios o no expresivos de ese núcleo esencial en el que consiste la garantía institucional, que, para el propio Tribunal son mayoría en el seno de la LBRL, se incardinan, desde el punto de vista competencial, en el art. 149.1.18 CE y tienen una distinta naturaleza desde el punto de vista constitucional y ordinamental» (F. 4). En definitiva, la legislación estatal de régimen local que identifique su fundamento en el artículo 149.1.18 no puede constituirse en canon de constitucionalidad de la legislación autonómica o estatal; sólo cuando tal legislación (por ahora, la Ley 7/85) desarrolle directamente los artículos 137 y 140 de la CE, podrá entenderse como canon de constitucionalidad. Luego sólo en la medida en que se regulen por el Estado los aspectos esenciales de la autonomía política de los entes locales (artículo 140 CE), a la hora de garantizar su participación en todos los asuntos que afecten a su círculo de intereses tutelados por la teoría de la garantía institucional de la Administración Local tendrá esa consideración de canon de constitucionalidad que ha de respetarse por la legislación de las CCAA.

64 STS DE 29 de septiembre de 2003, rec. 5167/98, LALEY. Ponente: BAENA DEL ALCÁZAR, mantiene una posición favorable a la existencia de una vinculación negativa, al amparo de los artículos 137 y 140 CE, 31 de la Carta Europea de la Autonomía Local, y en los artículos 55 a 59 del TRRL, aprobado por DL 781/86.

65 STC 1/2004, F 6: «... Sobre la base de esas garantías debe destacarse además que la primacía que para el Tratado y su Derecho derivado se establece en el cuestionado art. I-6 se contrae expresamente al ejercicio de las competencias atribuidas a la Unión Europea. No es, por tanto, una primacía de alcance general, sino referida exclusivamente a las competencias propias de la Unión. Tales competencias están delimitadas con arreglo al principio de atribución (art. I-11.1 del Tratado), en cuya virtud «la Unión actúa dentro de los límites de las competencias que le atribuyen los Estados miembros en la Constitución [europea] para lograr los objetivos que ésta determina» (art. I-11.2). La primacía opera, por tanto, respecto de competencias cedidas a la Unión por voluntad soberana del Estado y también soberanamente recuperables a través del procedimiento de «retirada voluntaria» previsto en el artículo I-60 del Tratado.» 
local constitucionalmente garantizada, sin que sea necesaria la previa autorización o definición de injustos por Ley, cuando estén en juego potestades locales indeclinables.

En cuanto al alcance de la previa definición legal y a la necesaria predeterminación de los tipos de injusto penal, de tal manera que quede asegurada una mínima homogeneidad en las distintas ordenanzas locales, la doctrina constitucional exige la necesaria predeterminación por Ley de los criterios generales de la antijuridicidad; concepto difícil de entender y que parece referirse a los elementos esenciales del injusto penal. Teniendo en cuenta, al contrario que en materia fiscal en donde las figuras impositivas y sus clases están determinadas y tienen perfiles conocidos, en materia sancionadora no existe un cuadro ideal de infracciones y sanciones general aplicable a todas las materias, concurriendo, especialmente, en las Ordenanzas Locales de Convivencia Ciudadana una tendencia a la dispersión y al casuismo. Para superar la dificultad que supone la existencia de un sin fin de comportamientos típicos que figuran en éstas ordenanzas $^{66}$, el TC establece una flexibilización de la «interpositio legis» que no requiere la descripción de todos los comportamientos típicos: «La flexibilidad alcanza al punto de no ser exigible una definición de cada tipo de ilícito y sanción en la ley, pero no permite la inhibición del legislador. Del art. 25.1 CE derivan dos exigencias mínimas, que se exponen a continuación. En primer término, y por lo que se refiere a la tipificación de infracciones, corresponde a la ley la fijación de los criterios mínimos de antijuridicidad conforme a los cuales cada Ayuntamiento puede establecer tipos de infracciones; no se trata de la definición de tipos - ni siquiera de la fijación de tipos genéricos de infracciones luego completables por medio de Ordenanza Municipal-sino de criterios que orienten y condicionen la valoración de cada Municipio a la hora de establecer los tipos de infracción».

El TC asume sin reconocerlo expresamente un concepto cuasi funcional de las potestades sancionadoras locales, que van a encontrar, curiosamente, un ámbito de aplicación similar al de los ingresos públicos sinalagmáticos - tasas y precios públicos - en los que la reserva de ley tributaria se limita a establecer los principios básicos de tasas y precios públicos sin definir los hechos imponibles de cada figura. La flexibilización es así mayor que en la relación ley-reglamento; tanto por resultar sencillamente imposible que la Ley defina cada tipo de ilícito, como pudiera desprenderse del principio de tipicidad penal, en una materia presidida por el casuismo, como por no exigir la previa definición de tipos, quedando un amplio papel a favor de la ordenanza local, y así se reconoce implícitamente en la STC 132/2001F 6: «En forma similar a como acabamos de recordar en relación con la reserva de ley tributaria, también la exigencia de ley para la tipificación de infracciones y sanciones ha de ser flexible en

66 Valentín MERINO ESTRADA (2006) «Las nuevas Ordenanzas municipales reguladoras de la convivencia ciudadana» REALA, nums. 300-301, enero-agosto de 2006 MAP. MADRID. 
materias donde, por estar presente el interés local, existe un amplio campo para la regulación municipal.»

Si se tiene en cuenta que la antijuridicidad es uno de los elementos esenciales de la infracción o delito y que requiere para su apreciación, en sentido material, que la acción del sujeto responsable transgreda una prescripción vinculante regulada en el Derecho Administrativo, lesionando o poniendo en peligro un bien jurídico que la norma administrativa quiere proteger para salvaguardar los intereses públicos afectados, y, en sentido formal, que la conducta se encuentre tipificada como infracción administrativa y no esté justificada por la concurrencia de algunas de las circunstancias que determinarían la inexigibilidad de responsabilidad, referir la reserva de Ley en materia sancionadora local al establecimiento de unos criterios mínimos de antijuridicidad, es hablar más de remisión normativa a un poder cuasi autónomo, que de reserva de ley en sentido estricto; en cuando a la naturaleza de la ordenanza local, supone un efecto práctico equivalente a la teoría de su vinculación con el resto del ordenamiento. Desde este punto de vista, era plausible y así se anunció por la doctrina $^{67}$ que la flexibilización autorizada por la nueva doctrina constitucional sólo requería el desarrollo o el establecimiento de criterios generales de antijuridicidad en la propia LBRL, limitados a señalar los criterios esenciales o nucleares de posibles tipos genéricos de injusto, referidos a conceptos tan abiertos como alterar el orden público, la seguridad y convivencia ciudadana, el deterioro o la destrucción de la propiedad pública, impedir o dificultar la prestación de servicios públicos e impedir el libre uso de los espacios públicos. Estableciendo los límites generales a las sanciones en atención a la culpabilidad personal y a la gravedad de los hechos o daños y de su transcendencia para la convivencia la tranquilidad, sin referencia alguna a los niveles de población.

La Reforma de la LBRL por la Ley 57/2003, confirmó por completo las previsiones doctrinales sobre el contenido mínimo necesario de la Ley para entender cumplidas las exigencias de la «interpositio legis» en materia penal local, con una intervención mínima limitada a establecer unos criterios de tipificación y sanción tan generales que, más que de previa definición de los aspectos nucleares de los injustos, puede hablarse de pleno reconocimiento de un poder normativo local sujeto y limitado por los principios constitucionales y por los principios generales del derecho administrativo sancionador. Sin llegar a una auténtica remisión normativa, teniendo en cuenta el amplio margen de las materias afectadas por el artículo 25.2 de la LBRL y la inevitable condición de materias de interés local de los servicios mínimos, los reservados y los obligatorios, hay que reconocer aquí, precisamente por la mayor rigidez de la reserva en materia penal, una mayor flexibilización que en materia propiamente impositiva, en la que la libertad de reglamentación local queda limitada a señalar bases y tipos $\mathrm{o}$ a reconocer las bonificaciones, desgravaciones y exenciones autorizadas, que

67 Juan Ignacio GOMAR SÁNCHEZ. Op. cit. n . 49, pag. 1651. 
la Ley pone a disposición de la ordenanza local. Sin que sea necesario tampoco detallar las sanciones a establecer, bastando al respecto una relación de las posibles sanciones que cada Ordenanza Municipal puede predeterminar en función de la gravedad de los ilícitos administrativos que ella misma tipifica.

\section{CRÍTICA DE LA DOCTRINA CONSTITUCIONAL EN MATERIA DE COMPETENCIAS SANCIONADORAS LOCALES}

La generosa interpretación del alcance de la interpositio legis (reserva de Ley penal en materia sancionadora local), limitada a señalar criterios generales de injusto y de su gravedad en correspondencia con unos límites a las sanciones a establecer, ha posibilitado la plena recuperación del poder local en materia de las tradicionales Ordenanzas Generales de Convivencia Ciudadana, con la notable extensión y complejidad que las caracteriza. Sin embargo, hay que advertir que cuando se trate del resto de las materias administrativas que se relacionan en el artículo 25.2 LBRL: urbanismo, medio ambiente, regulación de actividades recreativas y de ocio (policías especiales) o de intervención en la actividad privada a través del régimen de licencias y todo tipo de autorizaciones - por supuesto, cuando se trate de meras actividades de colaboración administrativa, de la prestación de servicios complementarios o de la prestación y gestión de los grandes servicios públicos como la sanidad y la educación, en general, en las distintas materias que figuran en el mismo artículo-, quizá ya no resulta tan sencillo y no sea posible limitar la «interpositio legis» a la previa definición de unos criterios genéricos. En los ámbitos y materias de indudable interés local, en los que no existen derechos consolidados de los particulares, salvo los temporales concedidos por el propio Ayuntamiento, la contradicción entre las imposiciones y necesidades del uso o servicio público y los intereses de la empresa privada o los derechos de los particulares se resuelve normalmente a favor del poder público municipal encargado de mantener el uso común general, de acuerdo con los principios de proporcionalidad y subsidiariedad, promovidos por la Carta europea de la Autonomía Local. Por el contrario, cuando se trate de sancionar conductas de actividades particulares que no tengan relación con el uso de los espacios e infraestructuras públicas y con los distintos servicios públicos, la existencia de otros títulos jurídicos a favor de los ciudadanos y la protección que ofrecen los distintos derechos fundamentales, y el derecho a la libertad de empresa, obligarán a una mejor y más extensa definición de los comportamientos y actuaciones injustas que puedan ultimarse por las ordenanzas locales. No es concebible una intervención generalizada de las ordenanzas sancionadoras locales en materia de actividades privadas ${ }^{68}$. Ni si-

68 Carles PAREJA I LOZANO «Autonomía y Potestad Normativa de las Corporaciones Locales» RAP Num. 138 pags. 107-14, septiembre-diciembre de 1995 (CEPC) MADRID. 
quiera cuando se trate del uso de espacios públicos, es posible que las ordenanzas locales definan supuestos especiales de responsabilidades objetiva de los organizadores de espectáculos o de los padres de los menores de edad. La STSJ de Castilla y León, 2169/2006, de 5 de diciembre, valida la reglamentación sancionadora de la Ordenanza del Ayuntamiento de Valladolid de Protección de la Convivencia y Prevención de Actuaciones Antisociales, pero anula aquellos preceptos destinados a regular una responsabilidad especial y objetiva de los padres de los menores y de los organizadores de espectáculos en bienes de dominio público, por carecer de título habilitante, al tratarse de materias reguladas por Ley Orgánica y, por ende, impenetrables para la reglamentación local, que debe utilizar los cauces ya establecidos en las leyes para exigir las respectivas responsabilidades.

En cualquier caso, el mayor déficit de la nueva doctrina constitucional no está en la definición del contenido de la interpositio legis, que se ha establecido con generosidad y en grado mínimo. El déficit de la nueva doctrina constitucional está en la falta de claridad de la Sentencia a la hora de incluir un poder sancionador en el interés local constitucionalmente protegido. La doctrina sobre la garantía institucional de la Administración Local sentada en las SS 27/87, de 27 de febrero, F. 4; 214/89, F 5, y 11/99, sólo identifica la existencia de un interés local con relevancia constitucional cuando existe una relación directa de la Ley (hoy LBRL) con la garantía constitucional del art. 137 CE, en definitiva los ámbitos constitucionales y legales de las competencias locales no son coextensos $^{69}$. Doctrina que se ratifica en S 159/2001 para consolidarse plenamente en la S 240/2006, que ya establece directamente que la LBRL sólo servirá como canon de validez de constitucionalidad en aquellos aspectos enraizables directamente en los arts. 137, 140 y 141 CE: sólo aquellos extremos de la LBRL que se puedan incardinar de forma directa en los artículos 137, 140 y $141 \mathrm{CE}$, de cuyo contenido no representen más que exteriorizaciones o manifestaciones, - dice el TC - forman parte de la autonomía local constitucionalmente garantizada, mientras que los que se refieran a aspectos secundarios o no expresivos de ese núcleo esencial en el que consiste la garantía institucional, que, para el propio Tribunal son mayoría en el seno de la LBRL, se incardinan, desde el punto de vista competencial, en el art. 149.1.18 CE y tienen una distinta naturaleza desde el punto de vista constitucional y ordinamental» (F. 4). Sin que la Sentencia aclare si el poder sancionador local es un mero desarrollo legal a in-

\footnotetext{
69 «Expresadas de este modo indiferenciado las normas de contraste, conviene ante todo, poner de manifiesto que los imperativos constitucionales derivados del art 137 CE, por un lado, y del art. 149.1.18 CE, por otro, no son coextensos. Para empezar, los destinatarios del artículo primero son todos los poderes públicos, y más concretamente todos los legisladores, en tanto el destinatario del segundo es cada legislador autonómico, en cuanto vinculado por la competencia normativa básica del legislador estatal acogida a dicho precepto. Pero, sobre todo, los límites que para el legislador autonómico se deriven eventualmente del art. 149.1.18 CE pueden tanto venir impuestos en cuanto concreción de la garantía de la autonomía local, como pueden no estarlos. En el mismo sentido, la STC 109/1998 F 1. ${ }^{\circ}$ distingue las respectivas esferas de la garantía de la autonomía local (art. $137 \mathrm{CE}$ ) y de la competencia normativa estatal sobre «bases del régimen jurídico de las Administraciones públicas» (art. 149.1.18 CE) como cánones no coextensos
} 
cluir en las bases de las entidades locales, y por lo tanto su existencia depende de la voluntad política, o es un imperativo constitucional, de obligada contemplación para el legislador.

La STC 132/2001 autoriza una flexibilización de la reserva de ley en todo el ámbito legal competencial local (artículo 25.2 LRL), sin reducirlo a los ámbitos protegidos por la Garantía Institucional de la Administración Local, pero mantiene un silencio hermético sobre si la garantía institucional o constitucional incluye o no necesariamente el ejercicio de un poder sancionador propio y de naturaleza cuasi funcional. Lo que permitiría recurrir ante el propio TC las distintas leyes -incluidas las básicas del Estado- que omitieran señalar los necesarios criterios generales de los respectivos injustos, los distintos tipos de infracciones de acuerdo con la gravedad de los hechos, y los elementos de gradación de las sanciones con el detalle suficiente para posibilitar una reglamentación local autónoma. En conclusión, la doctrina del TC vigente no asume un poder sancionador protegido por la garantía institucional de la administración local. Garantía que viene a fundamentar - en materias de interés local - una especial flexibilización de la reserva de ley pero un derecho constitucional a un poder normativo autónomo cuando exista un amplio campo para la regulación local.

Puede afirmarse, en consecuencia, que mientras el ejercicio del poder sancionador local esté condicionado por la necesaria y graciosa autorización del Estado o de la respectiva Comunidad Autónoma, no existe la autonomía local que establece la $\mathrm{CE}$, puesto que las normas jurídicas no son concebibles sin una sanción por incumplimiento y lo característico de la autonomía es la configuración de un ordenamiento propio, dentro del ordenamiento global presidido por la Constitución. La Autonomía Local no sólo implica la existencia de un interés local protegido para el ejercicio de unas competencias propias e indeclinables, sino que exige el reconocimiento de un poder sancionador en el ejercicio de tales competencias que tanto puede ser en negativo, según la fórmula «de acuerdo con las leyes y con los criterios generales de las infracciones y sanciones administrativas y con respeto a los derechos constitucionales», al igual que figura en los artículos 55 a 59 del TRRL, modificando la referencia de las sanciones a criterios de gravedad, como articularse como una obligación del legislador básico a incluir directamente en las bases del régimen local.

El desarrollo legislativo de la nueva doctrina constitucional aprobado por la Ley 57/2003, de Medidas para la Modernización del Gobierno Local, artículos 139 a 141, limita el establecimiento de los criterios generales de antijuridicidad a las relaciones de convivencia y al uso de sus servicios, equipamientos, infraestructuras y espacios públicos. El legislador básico anuda la nueva doctrina constitucional sobre flexibilización del principio de reserva de Ley penal a un elenco muy limitado de materias (espacios y servicios públicos) de indudable interés local y directamente enraizables en la autonomía local, que pueden identificarse con los servicios mínimos y los obligatorios y con las tradicionales 
Ordenanzas de Policía y Buen Gobierno, cuando se trate de conductas no subsumibles en la LO 1/92, de Seguridad Ciudadana. No es fácil, en definitiva, extender la flexibilización propuesta en la STC 132/2001 a todos las materias relacionadas en el artículo 25.2 de la LBRL, en los que existe un interés o una presencia local de muy diversa intensidad o, directamente, son servicios de titularidad estatal o comunitaria en los que la presencia local no tiene una especial relevancia ${ }^{70}$. Sólo la realidad de un interés local prevalente puede garantizar la atribución de una competencia sancionadora directa por la propia Ley de Bases de Régimen Local y ésta solo puede referirse a los espacios y servicios públicos de indudable titularidad local por tratarse de servicios mínimos u obligatorios en los que no puede discutirse un poder normativo autónomo, que ahora puede regular y establecer un régimen sancionador propio. Por el contrario, cuando estemos en el supuesto general de atribución indirecta de competencias, a través de la legislación material del Estado o de las Comunidades Autónomas, la atribución o no de competencias para establecer o desarrollar un régimen sancionador local propio requerirá habilitación específica. Es imposible autorizar una potestad sancionadora limitada a unos criterios de antijuridicidad cuando no se dispone de competencias materiales atribuidas por la legislación sectorial o éstas no incluyen un poder normativo o lo incluyen referido a aspectos meramente tangenciales de la materia.

En definitiva, es necesario reconocer que la atribución de un poder sancionador local forma parte de la autonomía local garantizada. En otro caso, carece de sentido la obligada reserva para una regulación local autónoma de las infracciones y sanciones locales que se anuncia en la tan citada STC 132/2001. Si existe un ámbito reservado para una regulación sancionadora local hay que reconocer que forma parte de la autonomía local constitucionalmente garantizada y es obligación, en principio, del legislador básico reconocerlo y posibilitarlo en todas las materias y servicios de indudable interés local. Desde el punto de vista de la autonomía local es más importante incluir la potestad sancionadora en la garantía institucional de los entes locales - lo que obliga al legislador básico u ordinario a la atribución efectiva de potestades sancionadoras en aquellas materias de indudable interés local, entre las que destacan el urbanismo y el medio ambiente-, que establecer una relativización de la reserva de Ley limitada a los criterios generales de antijuridicidad en todo el ámbito competencial local, que no es aplicable más que a los aspectos de indudable interés local y que tiene el carácter y la naturaleza de bases de las administraciones públicas 149.1.18 CE, por lo tanto variable en función de la voluntad política.

70 La STSJ Comunidad Valenciana, de 1 de mazo de 2007, se plantea la viabilidad de una vinculación negativa de la ordenanza local en ámbitos competenciales de indudable interés local, y suspende el régimen sancionador de la ordenanza municipal de medio ambiente recurrida por la Comunidad Valenciana. 


\section{Crónicas y Documentos}

REALA-2007, núm. 305. CASIMIRO LÓPEZ GARCÍA. RESERVA DE LA LEY PENAL Y AUTONOMÍA LOCAL 